NBER WORKING PAPER SERIES

\title{
PORTFOLIO CONCENTRATION AND \\ THE PERFORMANCE OF INDIVIDUAL INVESTORS
}

\author{
Zoran Ivković \\ Clemens Sialm \\ Scott Weisbenner \\ Working Paper 10675 \\ http://www.nber.org/papers/w10675 \\ NATIONAL BUREAU OF ECONOMIC RESEARCH \\ 1050 Massachusetts Avenue \\ Cambridge, MA 02138 \\ August 2004
}

\begin{abstract}
We extend our gratitude to an anonymous discount broker for providing the data on individual investors' trades, positions, and demographics. Special thanks go to Terry Odean for his help in obtaining and understanding the data set. We thank Marcin Kacperczyk, George Pennacchi, Sophie Shive, and Lu Zheng for useful insights and helpful discussions. Ivković and Weisbenner acknowledge the financial support from the College Research Board at the University of Illinois at Urbana-Champaign. Finally, we thank seminar participants at the University of Illinois and the University of Michigan for their comments and constructive suggestions. The views expressed herein are those of the authors and not necessarily those of the National Bureau of Economic Research.
\end{abstract}

(C)2004 by Zoran Ivković, Clemens Sialm, and Scott Weisbenner. All rights reserved. Short sections of text, not to exceed two paragraphs, may be quoted without explicit permission provided that full credit, including (C) notice, is given to the source. 
Portfolio Concentration and the Performance of Individual Investors

Zoran Ivković, Clemens Sialm, and Scott Weisbenner

NBER Working Paper No. 10675

August 2004

JEL No. D82, G11

\begin{abstract}
Using data on the investments a large number of individual investors made through a discount broker from 1991 to 1996 , we find that the stock trades by households with concentrated portfolios outperform those with diversified portfolios. While in general the stocks bought by individual investors significantly underperform the stocks they sell, the reverse is true for households whose holdings are concentrated in a few stocks. The excess return of concentrated relative to diversified portfolios is stronger for households with large account balances as well as for stocks not included in the S\&P 500 Index and local stocks, potentially reflecting concentrated investors' successful exploitation of information asymmetries. This finding is very robust to alternative concentration measures and regression specifications, and to alternative explanations such as differences across concentrated and diversified investors in the portfolio turnover and access to inside information, suggesting that some of these concentrated households have superior information processing skills. Moreover, controlling for a household's average investment ability, the household's trades perform better as the household's portfolio includes fewer stocks. However, while concentrated household portfolios on average outperform diversified ones, their levels of total risk are larger and the Sharpe ratios of their stock portfolios are lower.
\end{abstract}

Zoran Ivković

College of Business

University of Illinois

340 Wohlers Hall

1206 South Sixth Street

Champaign, IL 61820

ivkovich@uiuc.edu

Clemens Sialm

Department of Finance

University of Michigan Business School

701 Tappan Street

Ann Arbor, MI 48109-1234

and NBER

sialm@umich.edu
Scott Weisbenner

College of Business

University of Illinois

340 Wohlers Hall

1206 South Sixth Street

Champaign, IL 61820

and NBER

weisbenn@uiuc.edu 
Despite the longstanding and widespread financial advice to hold well-diversified portfolios, several studies have found that many individual investors instead tend to concentrate their portfolios in a small number of stocks. ${ }^{1}$ There are a few key reasons why households might hold poorly diversified portfolios. First, a lack of diversification could be prompted by behavioral biases such as familiarity ${ }^{2}$ or overconfidence. ${ }^{3}$ That is, households' investment decisions might be affected by a tendency to consider investing in only a relatively small subset of companies one is familiar with or confident in, though not necessarily informed about. Second, individual investors might hold concentrated portfolios because they are able to identify stocks with high expected abnormal returns. Under such circumstances, rational investors would need to assess the trade-off between the benefits of higher stock returns with the costs of higher total risk and the implications of combining such prospective investments with their existing portfolios. The main contribution of this paper is to compare the performance of investors with concentrated and diversified holdings and to shed some light as to why investors might hold undiversified portfolios.

If under-diversification is driven solely by behavioral effects, then concentrated household portfolios on average should not exhibit superior performance. For example, if portfolio concentration stems from familiarity bias or overconfidence, the holdings of concentrated investors will not earn superior returns on average relative to stocks held by diversified households. Indeed, in the context of 401(k) plans, Benartzi (2001) finds that concentrated allocations to company stock (one that its employees participating in its 401(k) plan are surely familiar with) do not predict future company stock returns. However, if households that have favorable information concerning a stock act upon this information by tilting their portfolio towards it, then the stock-picking ability of concentrated households should be superior to that of diversified households. Moreover, if informational advantages are the cause of the superior performance, the abnormal returns should be generated by investments that have greater

\footnotetext{
${ }^{1}$ See, for example, Blume and Friend (1975), Kelly (1995), Barber and Odean (2000), and Goetzmann and Kumar (2001).

${ }^{2}$ There is a body of evidence that investors tend to invest disproportionately in the companies with which they are relatively familiar. French and Poterba (1991) document a tendency for investors to favor domestic over international stocks. Huberman (2001) shows that the shareholders of a Regional Bell Operating Company tend to live in the area that it serves. Zhu (2002) and Ivković and Weisbenner (2004) show that individual investors who invest through a discount broker exhibit considerable local bias. In the context of 401(k)-plan investing, participants on average have considerable holdings in own-company stock (Benartzi (2001) and Liang and Weisbenner (2002)).

${ }^{3}$ Odean $(1999)$ and Barber and Odean $(2000,2001)$ show that individual investors tend to trade excessively and that such behavior is consistent with overconfidence.
} 
informational asymmetries (e.g., stocks not in the S\&P 500 Index, particularly those local to the investor).

Research in cognitive psychology suggests that there are limits to human capacity for processing information and conducting more than a limited number of tasks at a time and that such processing limitations might constrain human reasoning and problem solving. ${ }^{4}$ Cognitive limitations notwithstanding, in reasonably efficient financial markets, the availability of particularly insightful value-relevant information may be scarce and difficult to identify and the ensuing search costs may be prohibitively large. Assuming that the availability of relevant information and/or the information processing skills of investors are limited, households may be better off investing in a subset of the limited number of stocks with informational asymmetries. Expansions of the portfolio beyond this limited subset into additional stocks will likely depress portfolio performance, either because the stocks about which one may possess superior information have already been tapped or because the increasing number of different investments lessens one's ability to effectively monitor any of them.

The empirical literature studying the performance of individual investors finds that, on average, households' stock investments perform poorly. For example, Odean (1999) reports that individual investors' purchases tend to underperform their sales by a significant margin. Barber and Odean $(2000,2001)$ further show that, on average, individual investors who hold common stocks pay a substantial penalty in performance for trading actively. These results are consistent with the hypothesis that individual investors are overconfident and trade excessively.

On the other hand, certain individual investors have been found to fare better. Coval, Hirshleifer, and Shumway (2002) document that individual investors that have performed abnormally well in the past continue to perform abnormally well in the future. Thus, it appears that some skillful individual investors might be able to exploit market inefficiencies to earn abnormal profits. Ivković and Weisbenner (2004) find that households exhibit a strong preference for local investments and further show that, on average, individuals' investments in local stocks outperform their investments in non-local stocks, suggesting that investors are able to exploit local knowledge. The excess return is particularly large for stocks not included in the

\footnotetext{
${ }^{4}$ See, for example, Miller (1956), Piaget (1971), Bachelder and Denny (1977), Dempster (1981), Chapman (1990), Just and Carpenter (1992), and Cantor and Engle (1993).
} 
S\&P 500 Index, in regard to which informational asymmetries between local and non-local investors may be the largest.

Using data on the investments a large number of individual investors made through a discount broker from 1991 to 1996, we study the relation between the performance of households' trades and the concentration of their portfolios, with a particular focus on households with substantial account balances. Consistent with Odean (1999), we find that, on average, the stocks bought by individual investors underperform the stocks they sell by a wide margin. However, we find that the reverse is true for households with concentrated investments. Specifically, we find that the trades of concentrated households perform significantly better than the trades of diversified households (note that, throughout the paper, we use the term "diversified" rather loosely-simply to refer to investors who hold portfolios that are not concentrated in one or a few stocks, i.e., the opposite of concentrated investors). ${ }^{5}$ This result is particularly strong for households with large account balances. The purchases of diversified investors with account balances of at least $\$ 100,000$ underperform their sales by 1.8 percentage points per year. On the other hand, the purchases of concentrated investors with such large account balances outperform their sales by 3.0 percentage points per year. The excess return associated with concentration is stronger for investments in local stocks and stocks that are not included in the S\&P 500 Index (which tend to have less analyst coverage and national media attention), potentially reflecting concentrated investors' ability to exploit informational asymmetries. In sum, these findings are consistent with the hypothesis that skilled investors can exploit informational asymmetries by concentrating their portfolios in the stocks about which they have particularly favorable information.

Across all households, the stock picks made by concentrated investors outperform those made by diversified investors by about one percentage point over the year following the purchase, with the difference in performance growing to three percentage points for households with relatively large portfolios (i.e., $\$ 25,000$ or more) and to four percentage points for those with the largest portfolios (i.e., $\$ 100,000$ or more). However, the purchases made by concentrated households with small portfolios (i.e., less than $\$ 25,000$ ) do not outperform the purchases made by diversified households.

\footnotetext{
${ }^{5}$ However, as Goetzmann and Kumar (2001) point out, "diversified" investors may not be really diversified, as the correlations in returns among stocks within portfolios with many holdings can be fairly high.
} 
Unlike households with small portfolios, wealthy households have the resources to hold a larger number of stocks, if desired, and thus obtain the potential benefits of diversification. The fixed costs of purchasing securities make it uneconomical for households with limited wealth to hold a large number of securities directly. It is also likely that some wealthy households might have greater access to value-relevant information and might possess processing skills superior to those prevailing among households with smaller accounts, causing this portion of investors to concentrate their portfolios in a few investments.

This leads to two clear predictions. First, there should be a much greater dispersion in the diversification levels of large portfolios relative to small portfolios. Second, among households with large portfolios, concentrated investors should be better stock pickers, as informed investors may be under-diversified, holding substantial positions in the stocks with the most promising prospects, while uninformed investors would rationally hold a more diversified portfolio. Large household portfolios indeed display more variation in their diversification levels, potentially in accordance with the degree of their informational advantage. ${ }^{6}$ On the other hand, households with small portfolios may hold very few stocks because of fixed commissions and other trading costs and/or have less access to value-relevant information, leading to no relation between performance and concentration for this group of investors, while there is such a relation for investors with larger portfolios.

However, rather than reflecting investor stock-picking ability, the superior performance of concentrated households could also be attributed to alternative explanations such as differences across the two groups of investors in the volatility of stocks purchased, turnover of household portfolios, some omitted investor-specific variable like financial sophistication, and the exploitation of inside information. We explore these alternatives and show that they cannot explain the finding. A particularly compelling result is that the trades made by concentrated households outperform the trades made by diversified households even after adjusting for household fixed effects, that is, after controlling for households' average investment abilities. We also conduct several other robustness checks including exploring alternative measures of

\footnotetext{
${ }^{6}$ Specifically, households with stock portfolios of $\$ 100,000$ or more held 11.7 stocks on average with an interquartile range of $4-16$ stocks. The $10^{\text {th }}$ and $90^{\text {th }}$ percentiles were 2 and 24 stocks, respectively. However, households with stock portfolios less than $\$ 25,000$ or more held only 2.4 stocks on average with an interquartile range of $1-3$ stocks. Their $10^{\text {th }}$ and $90^{\text {th }}$ percentiles were 1 and 5 stocks, respectively.
} 
concentration and aggregating the trades and the holdings of concentrated and diversified investors to form portfolios.

We do not argue that investors should hold poorly diversified portfolios. The relation between performance and portfolio concentration among individual investors does not mean that simply altering one's portfolio to hold just a few stocks will improve its performance. Rather, it suggests that some investors with superior stock-picking ability exploit that advantage by concentrating their portfolio in a few stocks. Portfolio concentration only has benefits if the investor's informational advantage is sufficiently large and if the investor is sufficiently risk tolerant.

While we do find that, on average, wealthy households holding highly concentrated portfolios perform significantly better than households holding widely diversified portfolios, we also find that concentrated portfolios have substantially higher levels of total risk. Indeed, we show that, although concentrated household portfolios on average outperform diversified ones, their levels of total risk are larger and the Sharpe ratios of their stock portfolios are lower.

Our results are consistent with those reported by Kacperczyk, Sialm, and Zheng (2004), who study the diversification of actively managed equity mutual funds. They report that mutual funds that are concentrated in specific industries perform better than widely diversified mutual funds. They attribute those results to the skilled mutual fund managers' tendency to select their asset holdings from a limited number of industries, presumably because their expertise is linked to those industries.

The remainder of the paper is structured as follows. After describing the data sources and presenting summary statistics in Section I, in Section II we study the performance of the trades of households with varying degrees of portfolio concentration. Upon finding that the trades of concentrated households perform substantially better, particularly for households with large accounts, we further examine whether the superior performance is robust to the inclusion of investor fixed effects and is driven by investments in stocks regarding which there are likely to be greater informational asymmetries. Section III considers alternative explanations for the superior performance of the trades of concentrated individual investors we find in Section II, including checking for differences across concentrated and diversified investors in the access to and exploitation of inside information, the turnover in households' stock portfolios, and the volatility of transacted stocks. Section IV presents additional robustness checks, including 
portfolio analyses of the trades and stock positions of concentrated and diversified households, as well as a discussion of the risk-return tradeoff for concentrated investment strategies. Section V concludes.

\section{Data and Summary Statistics}

The primary data source used in this study, obtained from a discount broker, includes individual investors' monthly trades and positions over a six-year period between 1991 and 1996. The data set captures all the investments that 78,000 households made through the brokerage house, covering common stocks, mutual funds, bonds, foreign securities, and derivative securities. The data set also provides some additional information about the households such as their zip codes. See Barber and Odean (2000) for a detailed description of the data set.

We focus on the common stocks traded on the NYSE, AMEX, and NASDAQ markets. Common stock investments constitute nearly two-thirds of the total value of household investments in the sample. We use the Center for Research in Security Prices (CRSP) database to obtain information on stock prices and returns and COMPUSTAT to obtain several firm characteristics, including the location of the company headquarters. We exclude stocks that could not be matched with CRSP (they were most likely listed on local exchanges or traded over the counter).

\section{A. Concentration of Stock Holdings}

We use the Herfindahl Index as a measure of the concentration of the individual investors' stock holdings. The Herfindahl Index $H I_{h, t}$ of household $h$ at time $t$ is defined as the sum of the squared weights of each stock $i$ in the household portfolio $\left(w_{t, i}^{h}\right)$ :

$$
H I_{h, t}=\sum_{i=1}^{N}\left(w_{t, i}^{h}\right)^{2}
$$

The Herfindahl Index equals one if a household owns only one common stock, and an equally-weighted portfolio of $N$ securities has a Herfindahl Index of $1 / N$. The index decreases as households become more diversified across different securities. 
We present the basic portfolio characteristics of the households in our sample in Table I. The sample contains 268,734 household-year observations. The mean account balance of $\$ 45,604$ is substantially larger than the median balance of $\$ 13,865$. A large fraction of brokerage accounts have relatively small balances. Around two-thirds of households have portfolio values below $\$ 25,000$ and only nine percent of households have portfolio values above $\$ 100,000$.

Past studies have found that households do not tend to diversify their account holdings across a large number of common stocks. ${ }^{7}$ Indeed, in our sample, households own on average 3.9 stocks in their brokerage account and the average Herfindahl Index of household portfolios equals 0.62 . The median portfolio includes two stocks and has a Herfindahl Index of 0.56. One third of the households own only one stock, but this concentration is driven by the small accounts.

Among households with larger portfolios, however, we find large variation in the extent of portfolio diversification (recall that, throughout the paper, we use the term "diversified" rather loosely-we use it simply to refer to investors who hold portfolios that are not concentrated in one or a few stocks, i.e., the opposite of concentrated investors). Focusing on households with a stock portfolio of at least $\$ 100,000$, the $10^{\text {th }}$ and $90^{\text {th }}$ percentiles of the distribution of the number of stocks held are 2 and 24 stocks, respectively, while the $10^{\text {th }}$ and $90^{\text {th }}$ percentiles of the Herfindahl Index span from 0.07 to 0.93 . The average number of stocks increases substantially and the average Herfindahl Index decreases with the size of the account balance. For example, households with portfolio balances exceeding $\$ 100,000$ own on average 11.7 stocks and have a Herfindahl Index of 0.33, with 7.5 percent of the households concentrating all of their portfolio in one stock.

The aggregate holdings of households in the sample differ from the market portfolio. Households tend to overweight local stocks and stocks not included in the S\&P 500 Index. Slightly more than one-half of the holdings are held in stocks included in the S\&P 500 Index, while the S\&P 500 Index stocks represent around two-thirds of the total market capitalization of the U.S. stock market during the sample period. One-seventh of the holdings are held in stocks of companies headquartered less than 50 miles away from the respective households' residences, a figure substantially higher than the fraction that would be observed if individuals invested in the

\footnotetext{
${ }^{7}$ See, for example, Blume and Friend (1975), Kelly (1995), Barber and Odean (2000), and Goetzmann and Kumar (2001).
} 
market portfolio. ${ }^{8}$ The portfolios of wealthier households correspond more closely to the market portfolio, but the bias towards local, non-S\&P 500 stocks persists.

\section{B. Persistence of Concentration Levels}

To assess the persistence of our concentration measure, we compute the average Herfindahl Index over the following six years for households that initially held exactly one stock and therefore had an initial Herfindahl Index of one. The Herfindahl Index decreases on average to 0.79 after one year and to 0.69 after six years. These concentration measures remain above the unconditional average Herfindahl Index of 0.62 in our sample. The persistence is substantially stronger for households with initial portfolio values exceeding $\$ 100,000$. The Herfindahl Index of households that initially own one stock decreases to 0.85 after one year and to 0.79 after six years, which is substantially larger than the average Herfindahl Index of 0.33 for these wealthy households. We obtain similar results if we compute the correlation of Herfindahl Indices for the same household over time.

The persistence in portfolio concentration could reflect buy-and-hold investors who simply continue to hold their initial stock position. However, the concentration levels remain very high even for households that have substantial portfolio turnover. We compute the average Herfindahl Indices at different time horizons for households that own initially one stock and that make at least ten stock transactions during each year. The average Herfindahl Index equals 0.48 after one year and 0.40 after six years, indicating that even the households with substantial turnover remain concentrated in a relatively small number of stocks. Again, the persistence is even stronger for larger portfolios. Coval, Hirshleifer, and Shumway (2002) find strong persistence in the performance of individual investors' trades. The strong persistence in portfolio concentration, if coupled with superior returns to concentrated investments, offers a potential explanation for their finding.

\section{Comparison with Survey of Consumer Finances}

To gauge the extent to which our discount brokerage sample is representative of the overall population of U.S. individual investors, we compare some of their major portfolio characteristics with the portfolio characteristics of the general population. Given our aim to study

\footnotetext{
${ }^{8}$ See Zhu (2002) and Ivković and Weisbenner (2004).
} 
the relation between the concentration of a household's portfolio and its performance, it is useful to assess whether the stock holdings in the brokerage account likely represent a large or small portion of a household's overall portfolio. Table II compares basic household portfolio characteristics from our sample with total household portfolio characteristics from the Federal Reserve Board's Survey of Consumer Finances (SCF). The SCF is conducted every three years and collects balance sheet, pension, income, and other demographic characteristics of a sample of U.S. households. ${ }^{9}$ It reports the number of stocks held in households' taxable accounts and their total portfolio value. For direct comparison, we report stock holdings in taxable accounts for our brokerage house sample. The SCF over-samples wealthy households because these households own a disproportionate fraction of the financial assets; accordingly, we use the provided population weights to compute the distribution of the wealth and diversification levels.

We compare the characteristics of our discount brokerage sample from December 1992 with the 1992 SCF in Panel A and our sample in November 1996 with the 1998 SCF in Panel B. In December 1992, the average account balance of households in our sample was $\$ 44,707$, while the average account balance of the SCF households holding equity in a taxable account was $\$ 66,810$. On the other hand, the median household in our sample has a higher account balance $(\$ 13,869)$ than the median household in the SCF $(\$ 8,000)$, with the $75^{\text {th }}$ percentile of account balances being fairly close $(\$ 35,604$ in discount brokerage sample and $\$ 30,000$ in SCF). Conditioning on a stock portfolio of at least $\$ 100,000$, the median stock holdings of $\$ 181,355$ in the sample corresponds very closely with the median of $\$ 181,000$ in the SCF, with the interquartile range also similar across the two groups. Panel B shows that account balances are larger during the latter time period. For all but the largest stock portfolios, the distribution of account balances at the $25^{\text {th }}, 50^{\text {th }}$, and $75^{\text {th }}$ percentiles for the discount broker sample matches the distribution for the general population fairly well.

The distribution of the number of stocks in our discount brokerage sample also closely resembles the distribution in the SCF. Households in the discount brokerage sample owned on average 4.3 stocks in December 1992 and households in the 1992 SCF sample owned on average 4.0 stocks; in the latter period the average number of stocks held is 5.1 and 5.7 stocks, respectively. This indicates that that the diversification of households' complete stock portfolios, as measured by the SCF sample, is not substantially different from the diversification of the

\footnotetext{
${ }^{9}$ See Kennickell and Starr-McCluer (1994) for a detailed description of the SCF data set.
} 
stock portfolios held by households in the discount brokerage house sample. Overall, there is a close match between the two samples along several important portfolio characteristics.

\section{Summary Statistics for Trades}

Table III describes some summary statistics for the individual investors' stock transactions during the sample period. The complete sample includes 640,070 buy transactions and 552,832 sell transactions of common stocks made by households that had stock holdings at the end of the prior year (needed to construct concentration levels and portfolio-value cutoffs). We compute the performance of the trades for households with various portfolio values. In addition to our usual portfolio-value cutoffs, we also include summary statistics for households with a stock portfolio less than $\$ 25,000$ at the end of the prior year, because they typically make substantially smaller trades. Households with portfolio values above $\$ 100,000$ account for nine percent of the households in the sample, but they account for 28 percent of the transactions, while households with portfolios less than $\$ 25,000$ constitute about two-thirds of the households, but just over one-third of the trades. The size of the purchase and the sale transactions is related to the total portfolio value. The average stock purchase is $\$ 5,665$ for households with portfolios less than $\$ 25,000$ and $\$ 19,453$ for households with portfolio values of at least $\$ 100,000$.

Individual investors disproportionately favor trading local stocks and the stocks not included in the Standard \& Poor's 500 Index. Only about 40 percent of transactions involve the stocks included in the Standard \& Poor's 500 Index and around 15 percent of the transactions involve the stocks of firms headquartered within 50 miles of the investor. The last two rows of Table III summarize the excess returns of the purchases and the sales during the subsequent year. The excess returns are computed by subtracting the appropriate Fama and French (1992) benchmark portfolio return formed according to size and book-to-market deciles from the raw returns. Consistent with Odean (1999), we find that the stocks purchased perform on average worse than the stocks sold ${ }^{10}$ for all portfolio-value cutoffs. However, the underperformance is more substantial for the households with the smallest portfolio values. The stocks purchased by all households have an average excess return of -1.6 percent during the year following the purchase, while the stocks sold by all households have an average excess return of 0.2 percent,

\footnotetext{
${ }^{10}$ Odean (1999) finds that stocks purchased by individual investors have an average return of 5.69 percent and stocks sold have an average return of 9.00 percent in the year after the transaction. Odean attributes the result to individual investors tending to be overconfident and trading excessively.
} 
resulting in a performance differential of -1.8 percent over the year following a purchase relative to a sell. For portfolios of at least $\$ 100,000$, the difference in average one-year returns (purchases minus sales) is -0.9 percent. The difference in median returns following purchases and sales is similar.

\section{E. Portfolio and Trade Characteristics by Portfolio Concentration}

Table IV compares the characteristics of the trades made by households that own only one stock at the beginning of the year (i.e., completely concentrated households) with the characteristics of the trades made by households that own more than one stock. For various subsamples defined by portfolio size, we summarize the characteristics of household portfolios holding more than one stock in the first column and show the difference between the two groups of portfolios in the second column.

One issue related to this dataset is that the investors whose common-stock investments are concentrated might hold well-diversified mutual funds through the same broker or they might be well diversified by holding other securities in their accounts with other brokers or though other investment channels. While we cannot completely rule out the latter possibility, the comparison of our sample with the SCF samples (see Section I.C) suggests that the summary statistics associated with household investments held through this broker are very close to those of the SCF samples. In regard to the possibility that investors concentrated in common stocks might be well-diversified through mutual funds or other securities, we find that concentrated households are significantly less likely to hold other asset classes in their accounts with this brokerage house. Panel A of Table IV shows that 53.3 percent of diversified households and 33.5 percent of concentrated households own other asset classes in their accounts with this broker. While the fraction of households with diversified stock portfolios that hold other types of assets rises with the size of the stock portfolio (from $48.7 \%$ for households with stock portfolios less than $\$ 25,000$ to $70.8 \%$ for households with stock portfolios of at least $\$ 100,000$ ), the fraction of households with concentrated stock portfolios that hold other types of assets actually declines with the size of the stock portfolio (from $35.4 \%$ for households with stock portfolios less than $\$ 25,000$ to $21.8 \%$ for households with the largest stock portfolios of at least $\$ 100,000)$. Thus, households with concentrated stock holdings are no more likely to invest into other asset classes 
at this brokerage house than are households with diversified stock holdings, and in fact are less likely to do so.

Panel B of Table IV reports the characteristics of total stock transactions for concentrated and diversified households. While 55.6 percent of diversified households purchase at least one stock in a given year, the same is true for only 32.5 percent of concentrated households. Moreover, the number of purchases is significantly lower for concentrated households than for diversified households even after conditioning on having at least one purchase in a given year.

The median total value of annual common-stock purchases made by the diversified households that made any common-stock purchases is $\$ 13,375$. The value of the purchases increases significantly with the total household portfolio value at the beginning of the year. The median household with buy transactions in a given year tends to add funds to the account because the total costs of the purchases exceed the total proceeds from the sales. Concentrated households with relatively small initial balances (below $\$ 25,000)$ tend to increase their portfolio values by more than the diversified households. However, this tendency reverses as the account size increases. Specifically, the sale proceeds of the concentrated households with account values exceeding \$100,000 are actually slightly larger than the costs of the total purchases, indicating that these concentrated households do not tend to add to their existing stock holdings, but rather use the proceeds of sales of existing positions to finance their new stock purchases. This finding is consistent with the persistence in concentration documented in Section I.B.

Panel C of Table IV describes the characteristics of individual purchases. The median purchase for all households is just below $\$ 5,000$ and does not depend significantly on the concentration level. Concentrated households with portfolio values of at least $\$ 25,000$ tend to execute substantially larger but less frequent trades than diversified households. For example, the median individual stock purchase by a diversified household with a portfolio value of at least $\$ 100,000$ is $\$ 9,128$, while the median purchase by such a concentrated household is about three times larger $(\$ 27,750)$. Regarding the type of stocks purchased, consistent with the hypothesis that households may concentrate holdings in stocks among which there are likely to be larger informational asymmetries, concentrated households are significantly more likely to purchase local stocks that are not included in the S\&P 500 Index.

Thus, investors who were concentrated at the prior year-end tend to make larger purchases in a few stocks while diversified investors tend to make smaller purchases in a greater 
number of stocks. Further, especially for households with sizeable portfolios, concentrated households in general remain concentrated because they tend to finance new purchases with the sales of existing positions.

\section{Performance of Trades}

In this section, we analyze whether the difference in performance between purchases and sales depends upon the initial concentration of the individual investors' portfolios. ${ }^{11}$ Upon finding that the trades of concentrated households perform substantially better, particularly for households with large accounts, we examine whether the "return to concentration" is robust to the inclusion of investor fixed effects and is driven by investments in stocks regarding which there are likely to be greater informational asymmetries.

\section{A. Estimation Methodology}

To determine the relation between the performance of trades and the concentration of the investor's portfolio, we consider several specifications. The first specification regresses the raw return of stock $i$ purchased by household $h$ at time $t$ during the subsequent year $\left(R_{i, h, t+l}\right.$ to $\left.t+12\right)$ on the Herfindahl Index of the household's portfolio at the end of the previous year (denoted as $\left.H I_{h, y-1}\right):^{12}$

$$
R_{i, h, t+1 \text { to } t+12}=\alpha+\beta H I_{h, y-1}+\varepsilon_{i, h, t+1} \text { to } t+12,
$$

Thus, the unit of observation is a stock purchased by a household at a specific point in time. The return is computed as the return during the year following the transaction. ${ }^{13}$ The coefficient $\beta$ represents the sensitivity of the return following the purchase, $R_{i, h, t+1}$ to $t+12$, to the initial Herfindahl Index of the portfolio $\left(H I_{h, y-1}\right)$. Thus, on average, the stock purchases made by

\footnotetext{
${ }^{11}$ Because holdings may simply reflect inertia, and thus be less directly related to information, examining positions might bias the results against identifying the information content embedded in the trades made by concentrated investors (which reflect direct investment decisions). Nevertheless, a robustness test that we report in Section IV.D (Table XI) suggests that the consideration of positions still uncovers a "return to concentration."

${ }_{12}$ As discussed previously, the concentration level is highly persistent. For example, the correlation between the Herfindahl Index values in two subsequent years is 0.79. Moreover, as shown in Table IV, concentrated households tend to offset the purchase of a new stock with the liquidation of an old position.

${ }^{13}$ When computing the return over the year following the transaction, the return calculation starts on the first day of the next month, ending on the last day of the $12^{\text {th }}$ month after the transaction. Hence, we will refer to the one-year return following the transaction as $R_{i, h, t+l}$ to $t+12$. This timing convention might understate the performance of skilled investors as excess returns might begin to accrue immediately after their transactions, an issue we address in Section IV.B (Table IX).
} 
perfectly concentrated households (i.e., $H I=1$ ) would have outperformed those made by perfectly diversified households (i.e., $H I=0$ ) by $\beta$ percentage points the year following the buy. ${ }^{14}$ Likewise, we separately estimate return regressions for the households' sales of common stocks.

We also relate the excess return of stock $i$ bought or sold by household $h$ at time $t$ during the subsequent year $\left(X_{i, h,+1}\right.$ to $\left.t+12\right)$ to the portfolio concentration of the household and to industry and momentum controls:

$$
X_{i, h, t+1 \text { to } t+12}=\beta H I_{h, y-1}+\gamma \boldsymbol{I I}_{i, t}+\delta \boldsymbol{I}_{\boldsymbol{t}} R_{i, h, t-12 \text { to } t}+\varepsilon_{i, h, t+l \text { to } t+12,}
$$

The excess returns are computed by subtracting the appropriate Fama and French (1992) benchmark portfolios formed according to size deciles and book-to-market deciles from the raw stock returns $R_{i, h, t+1 \text { to } t+12 .}{ }^{15}$

For this regression, the industry and momentum controls are interacted with indicator variables for the month of the transaction. To control for overall industry performance in the year following the transaction we include in the regressions the vector of industry indicator variables $\boldsymbol{I I}_{i, t}$ which corresponds to the 5,183 industry-month fixed effects based on the 73 distinct twodigit SIC codes and the 71 months a transaction could occur (from January 1991 to November 1996). To control for momentum, we include an interaction term between the lagged one-year return $R_{i, h, t-12}$ to $t$ and indicator variables for the 71 time periods (the coefficient vector $\delta$ corresponds to the 71 sensitivities of current returns to past returns). The standard errors are robust and take into account heteroskedasticity and cross-sectional correlation (e.g., the same stock being transacted in the same month by multiple investors).

Finally, we combine the purchases and the sales by estimating two specificationsanalogously to Equations 2 and 3, one for raw returns and another for excess returns - that include an indicator variable for purchases $\left(B U Y_{i, h, t}\right)$ and an interaction term between the purchase indicator variable and the Herfindahl Index $\left(B U Y_{i, h, t} \times H I_{h, y-1}\right)$ :

\footnotetext{
${ }^{14}$ We denote households that have a Herfindahl Index of one as perfectly concentrated households and households that have a Herfindahl Index of zero as perfectly diversified households. Of course, households cannot literally have a Herfindahl Index of zero because the index ranges between $1 / N$ and one, where $N$ is the number of available securities. However, in practice, the Herfindahl Index can take on values very close to zero for portfolios consisting of many stocks (that is, for large $N$ ).

15 The returns on these benchmark portfolios are obtained from Kenneth French's website: http://mba.tuck.dartmouth.edu/pages/faculty/ken.french/Data_Library.
} 


$$
\begin{aligned}
& R_{i, h, t+1 \text { to } t+12}=\alpha+\beta_{0} B U Y_{i, h, t}+\beta_{1} H I_{h, y-1}+\beta_{2} B U Y_{i, h, t} \times H I_{h, y-1}+\varepsilon_{i, h, t+1} \text { to } t+12, \\
& X_{i, h, t+1 \text { to } t+12}=\beta_{0} B U Y_{i, h, t}+\beta_{1} H I_{h, y-1}+\beta_{2} B U Y_{i, h, t} \times H I_{h, y-1}+\gamma \boldsymbol{I I}_{i, t}+\delta \boldsymbol{I}_{\boldsymbol{t}} R_{i, h, t-12 \text { to } t}+\varepsilon_{i, h, t+1 \text { to } t+12 .}
\end{aligned}
$$

The indicator variable $B U Y_{i, h, t}$ equals one if the corresponding transaction is a purchase and zero if it is a sale. The average return of a purchase made by a household with a perfectly diversified portfolio $(H I=0)$ exceeds the average return of a sale made by a household with a perfectly diversified portfolio by $\beta_{0}$. The average return of a sale made by a household with a perfectly concentrated portfolio $(H I=1)$ exceeds the average return of a sale made by a household with a perfectly diversified portfolio $(H I=0)$ by $\beta_{1}$. The coefficient on the interaction term of the buy indicator variable and the Herfindahl Index of the portfolio, $\beta_{2}$, is a key summary statistic of this study. It estimates the extent to which the trades (purchases and sales) made by concentrated households outperform those made by diversified households. Specifically, $\beta_{2}$ estimates the difference between (1) the difference between average performances of purchases and sales made by perfectly concentrated households and (2) the difference between average performances of purchases and sales made by perfectly diversified households. The coefficient $\beta_{2}$ can be interpreted as a measure of the "return to concentration."

While sales of stock can be motivated by information, they can also be the result of liquidity needs and tax considerations (e.g., tax-loss selling in December or before the asset loses short-term holding period status). Stock purchases, on the other hand, are not a result of the latter two motivations, and thus are more likely to reflect the investors' financial sophistication. Moreover, sales could be motivated by the "disposition effect" (i.e., loss-aversion, Odean (1998)), a tendency to sell good performers and retain poor performers in the portfolio. ${ }^{16}$ Thus, by excluding the sale decisions and only capturing the difference in performance of the stock purchases made by concentrated investors and the stock purchases made by diversified investors, an alternative "return to concentration" measure (the sum $\beta_{1}+\beta_{2}$, labeled as "Herfindahl + Buy indicator * Herfindahl" in the tables) captures precisely the transactions most likely to be based

\footnotetext{
${ }^{16}$ Assume, for example, that concentrated investors are good stock pickers, and that their sales are motivated by the disposition effect. If the good performers that are sold continue to perform well after the sale, that would bias against finding a return to concentration as the concentrated investor that makes good stock picks would also sell stocks that will likely continue to perform well.
} 
on asymmetric information and, at the same time, the least likely to be affected by other considerations.

\section{B. Estimation Results}

The one-year returns following purchases and sales made by individual investors with varying levels of concentration are summarized in Table V. Panel A of Table V summarizes the regression coefficients on the portfolio Herfindahl Index for the purchases of stocks for various samples of households. For each sample, the first column corresponds to the first specification using raw returns (Equation 2) and the second column corresponds to the second specification using excess returns relative to the Fama-French size and book-to-market decile portfolios and controlling for momentum and industry effects (Equation 3). Focusing first on the raw-return results, the coefficient estimate associated with the Herfindahl Index is significantly positive for households with initial portfolio values of at least $\$ 25,000$, with the relation between concentration and performance strengthening for households with larger accounts. For households with smaller initial portfolios (i.e., less than \$25,000), there is no significant difference in the performance of purchases with respect to household portfolio concentration. For example, in keeping with the interpretation of the coefficients on the Herfindahl Index as the total effect of concentration on trade performance when comparing a perfectly concentrated investor (Herfindahl Index of one) to a perfectly diversified investor (Herfindahl Index of zero), stocks purchased by perfectly concentrated households outperform stocks purchased by perfectly diversified households by 2.3 percent per year in the sample of households with portfolio values of at least $\$ 25,000$. The return differential further increases to 3.9 percent among households with account balances of at least $\$ 100,000$.

The second columns associated with the respective samples in Panel A correspond to the coefficient estimates after controlling for various risk, industry, and style characteristics. With the exception of the sample of households with stock portfolios less than $\$ 25,000$, all coefficients associated with the Herfindahl Index are significantly different from zero at the one percent level. For example, among households with portfolios of at least $\$ 25,000$, purchases made by concentrated investors outperform those made by diversified investors by 2.9 percentage points over the course of the year following the purchase. This percentage grows to 3.7 for households with portfolios of at least $\$ 100,000$. 
Panel B reports results pertaining to stock sales, which indicate that, unlike stock purchases, there is no significant relation between concentration and performance following the transactions. This asymmetry of purchases and sales in regard to the relation between concentration and returns likely reflects the notion that sales can be driven by many factors other than information about the stock's prospects, such as liquidity needs, taxes, and portfolio rebalancing. Besides, investors can only sell the stocks they already own. ${ }^{17}$ In contrast, no such limitations apply to stock purchases. Therefore, purchases made by concentrated investors on average likely contain more information about a stock's prospects than their sales.

Finally, Panel C combines the purchases and the sales. The first column reports the coefficient estimates based on the specification from Equation 4 and the second column reports the estimates based on the specification from Equation 5. The coefficient on the buy indicator, $\beta_{0}$, is significantly negative for all specifications and remains remarkably stable for various household portfolio sizes. On average, the buys made by perfectly diversified investors underperform the sales by 2.1 percent per year using raw returns and by 1.6 percent after the risk, industry, and style adjustments. These estimates are consistent with Odean's (1999) results that individual investors' purchases underperform their sales. The coefficient on the Herfindahl Index, $\beta_{1}$, is not significantly different from zero, confirming our previous result that the performance of the sales does not differ between concentrated and diversified households.

We find that the coefficient on the interaction term of the buy indicator variable and the Herfindahl Index of the portfolio, $\beta_{2}$, is positive and significantly different from zero for all but the households with the smallest portfolios. Thus, the differential performance following purchases relative to sales is consistently higher for concentrated households: controlling for risk, industry, and style, the differential performance following purchases relative to sales for concentrated households is 80 basis points per year higher than that for diversified households, rising to a difference of 2.4 percentage points for investors with portfolios of at least $\$ 25,000$ and 4.8 percentage points for those with portfolios of at least $\$ 100,000$. Thus, the trades of concentrated investors perform significantly better than those of their more diversified counterparts.

Panel $\mathrm{C}$ of Table $\mathrm{V}$ also reports an alternative measure of the return to concentration, namely the sum $\beta_{1}+\beta_{2}$, which measures the performance of purchases made by perfectly

\footnotetext{
${ }^{17}$ A potential exception would be short sales. However, very few investors in the sample place short sales.
} 
concentrated households relative to purchases made by perfectly diversified households. This measure tends to be positive in the analyses based on the sample of all households, though the magnitude of the coefficient is only statistically significant for the specification including controls for risk, industry, and style (coefficient estimate of 90 basis points per year). However, for larger account sizes, the difference in the performance following stock purchases across concentration levels increases substantially: depending on the specification, households with portfolio values of at least $\$ 25,000$ are associated with performance differentials of 2.3-2.9 percentage points per year, whereas the purchases of concentrated investors outperform those of diversified investors by almost four percentage points or households with portfolio values of at least $\$ 100,000$. These findings are consistent with the hypothesis that some households, particularly wealthy ones, have informational advantages that induce them to hold concentrated portfolios. $^{18,19}$

\section{Controlling for Investors' Average Stock-Picking Abilities}

A concern with any cross-sectional analysis is that some omitted household-specific attribute can explain the observed correlation (in this case between the concentration of investor portfolios and the performance of an investor's trades). To control for investor-specific attributes such as financial sophistication, we augment the previous specifications with household-level fixed effects. For example, we estimate the specifications based upon Equations (4) and (5) that also include fixed effects for each household as follows:

\footnotetext{
${ }^{18}$ Throughout the paper, we use the Herfindahl Index of the household's stock portfolio at the end of the prior year as our primary measure of concentration. An alternative concentration measure, such as the inverse of the number of stocks in the portfolio, yields very similar results. For example, the trades of perfectly concentrated households outperform those of perfectly diversified households by 2.4 percentage points using the Herfindahl Index measure and by 2.3 percentage points using the inverse of the number of stocks measure, with the comparable estimates 4.8 and 4.7, respectively, for the households with the largest portfolios.

${ }^{19}$ We also run Fama-MacBeth (1973) regressions to test whether the results are robust in the various cross-sections. Focusing on households with stock portfolios of at least $\$ 25,000$, the time-series mean (median) of the differences in the performance of the trades across the two investor groups $\left(\beta_{2}\right)$ is $2.7(2.0)$ percentage points and is highly statistically significant. The trades made by perfectly concentrated households perform better than the trades made by perfectly diversified households in 51 of the 71 cross-sections. We also consider our alternative return to concentration measure, the difference in the one-year excess returns following purchases for concentrated investors relative to diversified investors (again focusing on households with portfolios of at least $\$ 25,000$ ). The distribution of this alternative measure is very similar to the prior one, with a time-series average (median) of 3.5 (2.5) percentage points. Further, the purchases made by perfectly concentrated households perform better than those made by perfectly diversified households over the following year in 54 of the 71 cross-sections. Thus, both return to concentration measures appear to be a stable phenomenon in that they do no appear to be driven by unusually high returns in relatively few time periods.
} 
$R_{i, h, t+1}$ to $t+12=\beta_{1} H I_{h, t-1}+\beta_{2} B U Y_{i, h, t} H I_{h, t-1}+\mu I_{h} B U Y_{h}+\eta I_{h} S E L L_{h}+\varepsilon_{i, h, t+1}$ to $t+12$

$X_{i, h, t+1 \text { to } t+12}=\beta_{1} H I_{h, t-1}+\beta_{2} B U Y_{i, h, t} H I_{h, t-1}+\gamma I_{i, t}+\delta I_{t} R_{i, h, t-12 \text { to } t}+\mu I_{h} B U Y_{h}+\eta I_{h} S E L L_{h}+\varepsilon_{i, h, t+l}$ to $t+12$,

where $I_{h} B U Y_{h}$ and $I_{h} S E L L_{h}$ denote that separate household fixed effects are included for buys and sales, thus controlling for the average stock-picking ability (both for purchases and sales) of the household. The buy indicator variable, $B U Y_{i, h, t}$, is not included in the regression by itself, as it is absorbed in the household fixed effects.

Assuming that the availability of relevant information and/or the information processing skills of investors are limited, households may be better off investing in a subset of the limited number of stocks with informational asymmetries. Expanding the portfolio beyond this limited subset into additional stocks will likely depress portfolio performance, either because the stocks about which one may possess superior information have already been tapped or because the increasing number of different investments lessens one's ability to effectively monitor any of them. The specification that includes fixed effects is suitable for testing this hypothesis.

Results are presented in Table VI. The first two columns replicate the first two columns from Table $\mathrm{V}$, whereas the last two columns present estimates based on specifications that include fixed effects. The full sample consists of 52,661 households. All the returns are expressed in percentage points. In short, all the major conclusions from Table V hold. Both measures of the return to concentration (Panel C, Table VI) are large and positive - in fact, they are even larger than the estimates based on specifications that do not include household fixed effects. For example, the return to concentration is estimated at $2.4-2.7$ percentage points in the excess return specification. The strong return to concentration results obtained from fixed-effect specifications constitute a particularly compelling result because they suggest that, even after controlling for a household's average investment ability, the household's trades perform better as the household's portfolio includes fewer stocks.

\section{Interactions with Measures of Asymmetric Information}

Having demonstrated that the trades of concentrated households performed significantly better than the trades of diversified households, in this section we investigate whether this result can be explained by informational asymmetries. For example, Ivković and Weisbenner (2004) suggest that asymmetric information among investors is more prevalent for stocks that are local to the households and are less apt to be widely known (i.e., not included in the S\&P 500 Index), 
and, similar to individuals, Coval and Moskowitz (2001) show that mutual fund managers' local investments also outperform their non-local investments. It follows that the return to concentration could be the strongest for these types of stocks.

Table VII reports the estimated excess returns for the trades of perfectly concentrated and perfectly diversified households under the specification from Equation 5 (i.e., excess returns with industry-month and momentum controls). The first column reports the excess returns of the trades for all households with a known location. These estimates differ slightly from the basecase results in Table $\mathrm{V}$ because those results include households with and without known locations. The next four columns report one-year excess returns following trades of S\&P 500 stocks, non-S\&P 500 stocks, local stocks (i.e., the company headquarters is located within 50 miles of the household), and non-local stocks. The final four columns report returns based on the various interactions of the S\&P 500 status and locality of the stock. We observe larger differences between the excess returns of trades of perfectly concentrated and diversified households for stocks that are not included in the S\&P 500 Index (the third column) and are local to the household (the fourth column). For example, for all households with a known location, the trades of concentrated households outperform those of diversified households by 1.4 percentage points per year. However, focusing on the transactions of non-S\&P 500 stocks, the difference in the performance of trades is 2.4 percentage points, and focusing on the transactions of local stocks, the trades of concentrated households outperform those of diversified households by 5.0 percentage points.

The superior performance of the trades made by concentrated investors is particularly pronounced for local stocks excluded from the S\&P 500 Index (the eighth column), amounting to 6.9 percentage points for the sample of all households, thus indicating that exploiting informational asymmetries may play an important role in the return to concentration. Subsequent rows of the table suggest that the performance differential increases with the size of the household portfolio: from 6.9 percentage points for all households to more than 10 percentage points for households with larger portfolios-specifically, 13 percentage points for the sample of portfolios of at least $\$ 25,000$.

Thus, the "return to locality" for individual investors documented by Ivković and Weisbenner (2004) seems to be driven by the performance of the local investments made by concentrated investors. That said, concentrated investors still possess stock-picking skill in the 
realm of non-local stocks, as the trades of non-S\&P 500, non-local stocks by concentrated investors outperform those of diversified investors by 1.7 percentage points. On the other hand, among investments in S\&P 500 stocks, which have much greater analyst coverage and national media attention, there is no difference in the performance of the trades of concentrated versus diversified investors across all portfolio-value cutoffs.

\section{Alternative Explanations}

The results of Section II suggest that the trades of concentrated investors perform significantly better than those of diversified investors, with the difference being particularly striking when the comparison is made across households with large portfolios. While consistent with the hypothesis that concentrated investors, particularly those with large portfolios, are better stock pickers, this finding could also potentially be attributed to alternative explanations such as differences across the two groups of investors in the access to and exploitation of inside information, the turnover in households' stock portfolios, and the volatility of transacted stocks. In this section we examine and rule out these alternative explanations.

A. Relating Return to Concentration to Timing the Market, Exploiting Inside Information, and Holding Non-Stock Assets

In this section we consider three groups of alternative explanations for the return to concentration. First, we assess the possibility that strong returns to concentration stem from the concentrated investors' ability to time the overall market or its particular sector rather than from concentrated investors' stock-picking ability. Second, we test whether the return to concentration is driven by households transacting in the same stock over time, which could be consistent with receiving inside information. Finally, we also consider how returns to concentration differ across household portfolios with and without other non-common stock assets (e.g., mutual funds and bonds).

We report the differential returns following trades (buy returns minus sale returns) of perfectly concentrated investors relative to diversified investors $\left(\beta_{2}\right)$ for various samples in Table VIII. The first row replicates results from Table V for the full sample across various portfoliovalue cutoffs. In the second and third rows we replace the actual one-year return of the stocks bought and sold with either the return of the market (second row) or the return of the appropriate 
Fama-French portfolio formed based on size and book-to-market deciles (third row). This enables us to tell whether the performance of the trades of concentrated investors is attributable to specific stock-picking ability or to broader market timing. The results suggest the former, as the market and the appropriate Fama-French portfolio perform slightly worse following the trades of concentrated households relative to those of diversified households. Thus, the return to concentration is driven by concentrated investors transacting in the right stocks, rather than by timing the broad equity market.

In the next three rows (rows (4) through (6)), we exclude the stock(s) that represented the largest dollar-purchase or sale, the stock(s) that had the largest return following a purchase or the smallest return following a sale, and the $\operatorname{stock}(s)$ that had the greatest number of purchases or sales, respectively. All three screens serve as possible indicators that the individual has access to inside information for this particular stock, with the last exclusion similar to that made by Coval, Hirshleifer, and Shumway (2002). In each case, we not only exclude the particular transaction that was the largest in value or had the largest return, but we also drop any other household transactions involving that stock. Since we do this both for purchases and sales, at most the transactions involving two distinct stocks will be excluded from the sample for each household. These exclusions do reduce the return to concentration, however it still remains at about one-half to four-fifths of its original size for households with sizeable portfolios (i.e., at least $\$ 25,000$ ). For example, focusing on households with portfolios of at least $\$ 100,000$, the differential return of trades for concentrated households exceeds that for diversified households by 3.1 to 4.0 percentage points per year across the samples in which we exclude certain stock transactions, compared to 4.8 percentage points estimated over all trades. Thus, the superior performance of the concentrated investments in large portfolios is not predominantly attributable to the concentrated households transacting in the same stock over time. This result suggests that simply exploiting inside information is not likely the source of the return to concentration, but, rather, that households holding sizeable, concentrated portfolios have broader stock-picking ability.

In the last two rows (rows (7) and (8)), we assess whether investment ability differs across households with and without other non-stock assets (e.g., mutual funds and bonds). Clearly, a concentrated stock investment has a larger consequence for a household whose portfolio consists only of that stock than if the portfolio also consists of a broad-based equity 
mutual fund. Presumably, rational investors would not concentrate their entire portfolio in one or a few stocks unless they are very confident in their investment ability and the quality of the information they acquired. On the other hand, if such undiversified investments are the manifestation of overconfidence, then the trades of these households will not earn excess returns.

Results presented in the last two rows of Table VIII suggest that there clearly is a "courage in your convictions" effect, as the return to concentration documented throughout this paper is concentrated in the group of investors that do not hold assets other than common stocks with this brokerage house. Estimated over the full sample, there is no difference between the performance of trades among households with concentrated stock portfolios and those with diversified stock portfolios if the households also hold other non-stock assets. However, the trades made by concentrated households outperform those made by diversified households by 2.1 percentage points for the sample of households that only own stocks, with the performance of the trades increasing in the size of the portfolio. The difference in the return to concentration between the sample of investors that do not hold other assets and those that do is two to four percentage points and is significant across the full sample as well as the subsamples of investors with large portfolios. Thus, it appears that households that have superior information concerning a stock act upon this information by not only tilting their stock portfolio towards it, but by concentrating the bulk of their holdings (at least with this brokerage house) into this stock.

\section{B. Household Portfolio Turnover}

Table IV shows that concentrated investors purchase new stocks with a lower frequency than diversified investors. This may suggest that diversified investors have greater portfolio turnover than their concentrated counterparts. Barber and Odean (2000) find that "trading is hazardous to your wealth," that is, that households with greater portfolio turnover tend to earn lower returns. Thus, if the turnover of its portfolio is negatively related to the concentration of its portfolio, the return to concentration may not reflect investor stock-picking skill, but instead may simply be an artifact of the differential turnover across the two groups of households.

To address this issue, we calculate the average annual household portfolio turnover, defined as the average of the total buys and the total sales the household made during the year divided by the total portfolio balance at the beginning of the year (very similar to the turnover measure constructed by Barber and Odean (2000)). Across all households, the median annual 
portfolio turnover of concentrated investors (defined here as those holding one stock) is 4.1 percentage points lower than that for diversified investors. However, focusing on households with common-stock portfolios of at least $\$ 25,000$, the difference in annual turnover shrinks to 1.1 percent across the two groups (and disappears all together among households with commonstock portfolios of at least $\$ 100,000$ ), reflecting the offsetting effects of a lower propensity to purchase stocks with a higher transaction value conditional upon trade on the turnover of concentrated households relative to the turnover of diversified households.

In unreported analyses, we conduct a "horse race" between portfolio concentration on the one hand and average portfolio turnover on the other hand by re-estimating an augmented version of Equation 5 with two additional regressors: the household's average annual portfolio turnover over the sample, and an interaction of that term with the Buy indicator. The stocks purchased by households with higher average portfolio turnover over the sample performed worse than the stocks bought by households with low turnover, consistent with Barber and Odean (2000). The inclusion of the household's average portfolio turnover, while significant in it own right, does not diminish the return to concentration. ${ }^{20}$ For example, our primary return to concentration measure, $\beta_{2}$, is 0.8 percentage points across the sample of all trades made by all households both with and without portfolio turnover controls, and changes little for the sample of trades made by households with the largest portfolios (4.8 percentage points without turnover controls and 4.7 with turnover controls). ${ }^{21}$ This reflects that turnover is not that different between concentrated and diversified investors (particularly those with larger accounts); households with diversified-stock holdings tend to transact more than concentrated investors do, however, the trades of concentrated investors are larger, resulting in similar turnover levels.

\section{Stock Volatility}

Throughout the paper we report simple arithmetic returns. A potential concern with the return to concentration is that it could be a manifestation of concentrated households investing in riskier stocks (i.e., those with greater volatility). It is well known that if stock returns are lognormally distributed, then two stocks with the same average logarithmic returns will have

\footnotetext{
${ }^{20}$ Including the household's turnover during the year preceding the transaction, rather than the average of the household's annual portfolio turnover throughout the sample, does not effect the relation between trade performance and portfolio concentration. However, the turnover coefficients are now smaller in magnitude and insignificant.

${ }^{21}$ Including household portfolio turnover during the year preceding the transaction also does not diminish the estimated return to concentration in specifications with investor fixed effects.
} 
different simple arithmetic returns if their standard deviations differ (higher volatility leads to a higher average arithmetic return). In this case, the higher-volatility investments held by concentrated investors would mechanically have higher average one-year simple arithmetic returns, even if these investors had no investing skill relative to diversified households, just by virtue of the right-skewness of the return distribution.

The purchases of concentrated households (defined in this case as those holding only one stock) do have a higher monthly volatility that those of diversified households, however the difference is slight (13.1 vs. 12.5 for all households and 12.8 vs. 12.0 for households with accounts of at least $\$ 100,000$ ). However, concentrated households are also more apt to sell slightly more volatile stocks as well (13.1 vs. 12.4 for all households and 12.5 vs. 11.8 for households with the accounts of at least $\$ 100,000)$. Given that our primary return to concentration measure is the differential performance of trades (performance of purchases minus performance of sales) across the two investor-types, the level of volatility should not mechanically affect this difference in returns. Since both the stocks bought and sold have the same volatility on average for both groups of investors, any bias in arithmetic returns is effectively differenced out.

Nonetheless, to test for this potential alternative explanation for the return to concentration we conduct a "horse race" between portfolio concentration and volatility of the transacted stock. In unreported analyses, we re-estimate Equation 5 with the addition of the monthly volatility over the past 24 months and an interaction of that term with the Buy indicator. Including the volatility of the transacted-stock in the return regression actually has little effect on the return to concentration, suggesting that focusing on the differential performance of trades across investor groups mitigates any potential bias in average raw returns that can result from greater volatility.

Yet another way to address the potential role volatility can play in boosting the mean simple return is to use logarithmic returns instead of simple raw returns in the regression. In unreported analyses we find that a regression using log returns instead of regular raw returns estimates that, among portfolios of at least $\$ 100,000$, the differential performance following purchases relative to sales for concentrated households is 3.3 percentage points per year higher than that for diversified households, a figure similar to the 4.4 percent estimated with simple returns (as presented in Table V). 


\section{Further Robustness Tests}

Building upon the results of the previous sections, we conduct several other robustness tests including exploring alternative measures of concentration, considering alternative investment horizons, and aggregating the trades and the positions of concentrated and diversified investors to conduct a portfolio analysis. The section concludes with a discussion of the riskreturn tradeoff of the concentrated investment strategies employed by some of the investors in our sample.

\section{A. Alternative Specifications and Concentration Measures}

We begin this section by reporting on the results using four alternative specifications. The first focuses on transactions above $\$ 10,000$, the second weights each observation by the total value of the transaction, the third replaces the Herfindahl Index with the inverse of the number of stocks held in the household portfolio, and the fourth caps the distribution of returns following transactions at the top one percent to test if these extreme returns affect our results. In sum, both measures of the return to concentration are unaffected by any of the four alternative specifications: the positive relation between portfolio concentration and trade performance remains robust both in terms of magnitude and statistical significance. For example, focusing on households with portfolios of at least $\$ 100,000$, the trades of concentrated households outperform those of diversified households by $2.7-4.7$ percentage points (depending on the specification), a range similar to the baseline estimate of 4.8 .

In unreported analyses, we further test whether there is a non-linear pattern between stock-picking ability and the concentration of the household's portfolio. The coefficient estimates for the squares of the Herfindahl Index are jointly statistically significant at the ten percent level except for the sample of households with portfolio values exceeding $\$ 100,000$ (the $p$-value is 0.12 for this specification). For any portfolio-value group, the stock returns following sales are concave with respect to the Herfindahl Index. The return following a sale actually starts to decline for households with a portfolio Herfindahl Index of 0.58 or more (for the "all households" regression) and a Herfindahl of 0.37 or more (for the "portfolio at least $\$ 100,000$ " regression). Focusing on the sample of portfolios of at least $\$ 100,000$, the point estimate for the one-year return following a sale is actually negative ( -1.5 percentage points) for a perfectly concentrated investor, indicating some market-timing ability as to when to unload stocks for this 
group of investors. On the other hand, the stock returns following purchases are convex and tend to be highest at very high levels of concentration. Taking into account non-linearities in the relation between concentration and performance slightly increases the returns of the buys relative to the sales for concentrated households.

\section{B. Alternative Return Horizons}

The analyses reported thus far have considered one-year returns starting from the beginning of the month following the month of the transaction. This timing convention might understate the performance of skilled investors as excess returns might begin to accrue immediately after their transactions. To address this issue, we consider one-year returns that begin accruing immediately after the day of the transaction, as well as over a variety of horizons: one week, one month, three months, and six months. Examination of holding periods shorter than a year enables one to better determine whether the return to concentration accrues primarily over the first few days or weeks following a stock purchase, or rather accrues over a longer horizon. In estimating the specifications that require the computation of excess returns, we use the six daily Fama-French (1992) benchmarks formed according to two size and three book-to-market groupings (the 100 Fama-French portfolios based on size and book-to-market deciles are not available with daily frequency). ${ }^{22}$ Aside from different horizons and slightly different computations of excess returns, the specification is quite analogous to that from Equation 5.

The results, presented in Table IX, suggest that the return to concentration is not attributable to short-term individual stock-timing (i.e., excess returns do not accrue immediately after the transaction). Generally, returns to concentration are only detectable starting at the threemonth horizon (Panel C, Table IX) and keep increasing proportionate to the duration of the horizon. For example, focusing on the transactions made by all households, the trades of concentrated investors outperform those made by diversified investors by 30, 70, and 100 basis points over the first three months, six months, and one year after the transaction, respectively, while the differential performance of trades is $1.5,2.9$, and 5.7 percentage points over these horizons for households with large portfolios, respectively. This suggests that the return to concentration builds up gradually; it is not a consequence of some sudden burst of information revealed to the public shortly after the stock purchase (e.g., early access to an earnings report). In

22 The returns on these benchmark portfolios are also obtained from Kenneth French's website: http://mba.tuck.dartmouth. edu/pages/faculty/ken.french/Data_Library. 
that sense, the return pattern prevailing in Table IX presents perhaps our most compelling evidence that the return to concentration stems from sources other than access to inside information.

We also study the relation between concentration and the performance of trades using longer investment horizons. In unreported results, we find that the magnitude of the differential performance following purchases relative to sales tends to increase with the investment horizon, but the estimates are no longer statistically significance beyond the three-year horizon.

\section{Portfolio Analysis of Trades}

In this section we provide an alternative test of whether the trades of concentrated investors outperform the trades of diversified investors. In particular, we aggregate the trades made by concentrated and diversified investors into portfolios to test whether the trades (i.e., return following purchases minus return following sales) made by concentrated households outperform those placed by diversified households. Thus, loosely speaking, this portfolio return is the analog of $\beta_{2}$, the return to concentration, from Equation 5. Similar to Table VII, for various subsamples - trades in all stocks, trades in stocks classified according to their S\&P 500 Index membership status, trades in stocks characterized by the distance between the household and the corporate headquarters, as well as the interactions of the latter two criteria-we form zero-cost portfolios and evaluate their performance. Given we can no longer employ a continuous measure of concentration in the portfolio analysis (i.e., we need to categorize households as either concentrated or diversified), we define a concentrated investor as one with a portfolio Herfindahl Index of at least 0.5 at the prior year-end. ${ }^{23}$ A stock transaction is kept in the appropriate portfolio (buy/sale, concentrated/diversified) for 12 months, starting with the first full calendar month after the trade date, with transactions weighted by their value.

We compute raw and abnormal returns of various portfolios. The abnormal monthly returns are computed using Carhart's (1997) four-factor model, which accounts for the three Fama-French (1993) factors (market, size, and book-to-market factors), as well as the fourth momentum factor. We estimate the following regression:

$$
R_{i, t}-R_{F, t}=\alpha_{i}+\beta_{i, M}\left(R_{M, t}-R_{F, t}\right)+\beta_{i, S} S M B_{t}+\beta_{i, V} H M L_{t}+\beta_{i, m} M O M_{t}+e_{i, t}
$$

\footnotetext{
${ }^{23}$ We also consider other thresholds for the definition of a concentrated investor, such as a portfolio Herfindahl Index of 1.0 or at least 0.33 , and obtain qualitatively similar results.
} 
where the dependent variable is the return on portfolio $i$ in month $t$ minus the risk-free rate, and the independent variables are given by the returns of the standard four zero-investment factor portfolios. ${ }^{24}$ The intercept of the model, $\alpha_{i}$, is the Carhart measure of abnormal performance. The computation of standard errors follows the Newey-West correction and takes into account autocorrelation up to three lags.

Table X presents the results. Both panels in the table (pertaining to all households and to households with portfolios of at least $\$ 100,000$ at the prior year-end, respectively) confirm that the conclusions obtained with the pooled cross-sectional regressions in the prior tables also hold with the portfolio analysis. In particular, focusing on the sample of all trades made by all households, both the cross-sectional regression (Table V, second column) as well as the portfolio analysis (Table X, first column) suggest that the trades of concentrated investors outperform those of diversified investors by 0.8 percentage points on an annual basis. The portfolio results also confirm that the return to concentration is primarily attributable to non-S\&P 500 stocks (third column), as well as stocks local to the household (fourth column). Moreover, the intersection of these two criteria, presented in the eighth column, yields by far the strongest returns to concentration. For all households (Panel A), the risk-adjusted return is 59 basis points per month (7.3 percentage points annualized), comparable to the 6.9 estimated in the crosssectional regression (Table VII, eighth column). Again, the return to concentration measure is stronger for households with large portfolios, estimated at 23 basis points per month (2.8 percentage points annualized), compared with the 4.8 estimated in the cross-sectional regression (Table V, eighth column). ${ }^{25}$

We also consider the returns to a zero-cost portfolio that consists of purchases made by concentrated households on the long side of the portfolio and purchases made by diversified households on the short side of the portfolio. This zero-cost portfolio is a close equivalent of the alternative measure of the return to concentration (i.e., $\beta_{1}+\beta_{2}$ ). In unreported analyses, we find

\footnotetext{
${ }^{24} R_{M t}-R_{F t}$ is the excess return of the market portfolio over the risk-free rate. The market returns $R_{M t}$ are calculated as the value-weighted return on all NYSE, AMEX and NASDAQ stocks using the CRSP database. The monthly return of the one-month Treasury bill rate is obtained from Ibbotson Associates. $S M B$ is the return difference between small and large capitalization stocks. $H M L$ is the return difference between high and low book-to-market stocks, and $M O M$ is the return difference between stocks with high and low past returns. The size, value, and momentum factor returns are taken from Kenneth French's website:

http://mba.tuck.dartmouth.edu/pages/faculty/ken.french/Data_Library.

${ }^{25}$ Other thresholds for the definition of a concentrated investor, such as a portfolio Herfindahl Index of 1.0 or at least 0.33 , yield an estimate of the return to concentration of 28 basis points and 17 basis points per month for the households with large portfolios, respectively (with both estimates significant at the 10 percent level).
} 
that essentially all of the differential performance of trades is attributable to the purchases of concentrated investors outperforming those of diversified investors, with no differential in the performance following stock sales.

\section{Portfolio Analysis of Positions}

We explore the information content of not only the trades investors explicitly made, but also the implicit investment decisions associated with continuing to hold the existing investments. Toward that goal, we form and compute excess returns from a portfolio consisting of the accumulated holdings of households with concentrated investments and contrast those returns with the performance of a portfolio consisting of the stocks held by households with diversified holdings. We first form three portfolios to explore the relation between individual investor portfolio concentration and subsequent performance. The first portfolio-the "concentrated portfolio"-includes the stocks held by concentrated households, that is, those holding one or two stocks at the beginning of each month (the median stock ownership is two stocks in the sample). The second portfolio - the "diversified portfolio"-includes the stocks held by diversified households, that is, those holding more than two stocks at the beginning of each month. ${ }^{26}$ The holdings are kept in the portfolio for one month, after which time the portfolio is updated with the households' stock holdings at the end of the next month. We also compute the returns to a third, zero-cost portfolio that is long the concentrated portfolio and short the diversified portfolio. The portfolio returns are computed by value-weighting the returns of the individual stocks by their total value in the respective household portfolios. We form the portfolios based on holdings of all households, as well holdings of households with initial portfolio values above $\$ 100,000$, to test whether the results depend upon the portfolio value.

The structure of the columns of Table XI is the same as that of Table X. In each panel of Table XI, the first row reports excess returns from zero-cost concentrated portfolios, the second row reports excess returns from zero-cost diversified portfolios, and the third row reports their differences. In essence, Table XI confirms all of the key results obtained from Table X, except this time the inferences are based on a much broader set of investment choices that include not

\footnotetext{
${ }^{26}$ Here, we employ a concentration measure based on the number of stocks, rather than the portfolio shares, so as not to induce a positive correlation between the Herfindahl Index of the portfolio and subsequent household portfolio performance for investors that buy and hold good performers. We also consider other thresholds for the definition of a concentrated investor, such as holding only one stock or holding three or less, and obtain qualitatively similar results.
} 
only trades, but also holdings. Namely, the holdings of concentrated investors outperform those by diversified investors by 16 basis points per month (1.9 percentage points annualized) and by 41 basis points per month (5.0 percentage points annualized) for households with portfolios of at least $\$ 100,000$. Consistent with the analysis of trades, the return to concentration is stronger for non-S\&P 500 investments, as well as for investments local to the household, and is particularly strong for household investments in the intersection of the two categories.

\section{E. Risk-Return Tradeoff for Concentrated Investments}

Although we find that wealthy households holding highly concentrated portfolios perform significantly better on average than households holding widely diversified portfolios, we do not argue that investors should necessarily hold poorly diversified portfolios. Portfolio concentration only has benefits if the investor's informational advantage is sufficiently large and if the investor is sufficiently risk tolerant. After all, high portfolio concentration leads to an increase in idiosyncratic risk that a risk-averse investor might not be prepared to ignore.

To gauge the extent to which pursuing concentrated strategies affects the risk-return trade-off, we consider the time series of monthly household portfolios returns of the 14,702 households that have had at least 60 months of returns over the period from February 1991 to December $1996 .^{27}$ We again split the sample into concentrated and diversified households. The identifying criterion is the average annual portfolio concentration, computed as the arithmetic average of the concentration measures at the beginning of each year during the sample period. The portfolio concentration measure used in these analyses is the inverse of the number of stocks in the portfolio and the threshold that separates concentrated from diversified households is $0.5 .^{28}$

Table XII summarizes the average monthly household portfolio return, the standard deviation of these monthly returns, and the resulting Sharpe ratio for concentrated and diversified investors. The Sharpe ratio of a portfolio is defined as the ratio of the average excess monthly return of the portfolio above the risk-free rate divided by the standard deviation of the return of

\footnotetext{
${ }^{27}$ Requiring household returns for 60 months does not bias our results. In our sample, we find no evidence that individual investors systematically liquidated their positions because of their underperformance. Specifically, in unreported analyses, we regress the probability of a household liquidating its account during the year on the household's prior one-year portfolio return separately for each year. In no year was there a significantly negative relation between the prior portfolio return and the probability of liquidating the account.

${ }^{28}$ This choice of a concentration measure and the threshold effectively stipulates that the harmonic mean of the number of stocks held in the portfolio is two or less for concentrated households and is more than two for diversified households.
} 
the portfolio. Panel A suggests that concentrated households' time-series average of monthly returns exceeds that of the diversified households by 1.2 percentage points on an annual basis. It also suggests that, based on the cross-sectional distributions of returns across the two types of households, that portfolio performance varies quite a bit among both concentrated and diversified investors, although the dispersion in performance is greater among concentrated households. Panel B illustrates very clearly that greater concentration is associated with greater total portfolio risk. Indeed, the monthly standard deviations incurred by concentrated households exceed those incurred by diversified households by three percentage points, on average, with the $25^{\text {th }}$ percentile level of portfolio risk for concentrated investors (5.8 percentage points) roughly equal to the median level of risk for diversified investors (5.5 percentage points).

Finally, and not surprisingly in light of the results presented in Panels A and B, the riskreturn trade-off as characterized by the Sharpe ratio in Panel $\mathrm{C}$ suggests that the increased portfolio risk offsets the, on average, larger portfolio returns, resulting in a poorer risk-return tradeoff for concentrated households. For example, the average Sharpe ratio is 0.14 for concentrated investors, as compared to 0.18 for diversified investors, with the Sharpe ratio for diversified investors dominating that for concentrated investors at each point reported in the distribution.

That said, there are limitations to the inferences that can be drawn from the Sharpe ratios calculated in Table XII. To assess the marginal contribution of the concentrated stock investments made by some households to the household's overall risk-return profile, though, would require data on the overall household portfolio, including employer-sponsored retirement plans, real estate, and human capital. However, we can conclude that while the stock portfolios of concentrated households perform better on average, they do so with a higher standard deviation in returns.

\section{Conclusion}

This study provides a detailed insight into the relation between portfolio concentration and the performance of individual investors. As found by Odean (1999) and Barber and Odean (2000, 2001), many individual investors make poor investment decisions (e.g., the stocks they purchase underperform the stocks they sell). However, our results indicate that the investments made by households that focus their attention on a few securities tend to perform significantly 
better than those made by households that are diversified across many different stocks. For example, we find that the purchases of concentrated investors on average outperform their sales by a substantial margin (with the differential increasing with the size of the portfolio), while the purchases of more diversified investors significantly underperform their sales. Across all households, the stock picks of concentrated investors outperform those of diversified investors by about one percentage point over the year following the purchase, with the difference in performance growing to four percentage points for households with large portfolios (i.e., $\$ 100,000$ or more). Moreover, the trades of concentrated households outperform the trades of diversified households, even after controlling for household fixed effects. This is a particularly compelling result, as it suggests that controlling for households' average investment ability, households' trades perform better as household portfolios include fewer stocks. The "return to concentration" appears to be strongest for the stocks that likely have greater informational asymmetries. This finding is very robust to alternative concentration measures and regression specifications and to alternative explanations such as differences across concentrated and diversified investors in the volatility of transacted stocks, portfolio turnover, and access to inside information.

The correlation between the performance of trades and portfolio concentration does not mean that by simply altering one's portfolio to hold just a few stocks that performance will improve. Rather, it suggests that some investors with superior stock-picking ability exploit their skills by concentrating their portfolio in a few stocks. However, while the stock investments of concentrated individual investors have earned excess returns, on average, these portfolios also have increased total risk, and thus, on average, result in a worse risk-return tradeoff than the stock portfolios of diversified investors.

Coval, Hirshleifer, and Shumway (2002) document a strong persistence in the performance of trades of individual investors. We show that there is strikingly strong persistence in the concentration of households' portfolios over time, even among households with substantial turnover. The strong persistence in portfolio concentration coupled with the return to concentration - the key finding of our paper - offer a compelling explanation for their finding. Our results are also consistent with Kacperczyk, Sialm, and Zheng (2004), who report that mutual funds that are concentrated in specific industries perform better than widely diversified 
mutual funds. Thus, at least in the context of the performance of stock investments, it appears that for both individuals and professional money managers sometimes less can be more. 


\section{References}

Bachelder, B. L., and M. R. Denny, 1977, A theory of intelligence: I. Span and the complexity of stimulus control, Intelligence 1, 127-150.

Barber, Brad, and Terrance Odean, 2000, Trading is hazardous to your wealth: The common stock investment performance of individual investors, Journal of Finance 55, 773-806.

Barber, Brad, and Terrance Odean, 2001, Boys will be boys: Gender, overconfidence, and common stock investment, Quarterly Journal of Economics 116, 261-292.

Benartzi, Shlomo, 2001, Excessive extrapolation and the allocation of 401(k) accounts to company stock, Journal of Finance 56 (5), 1747-1764.

Blume, Marshall E. and Irwin Friend, 1975, The asset structure of individual portfolios and some implications for utility functions, Journal of Finance 30 (2), 585-603.

Cantor, J., and R. W. Engle, 1993, Working memory capacity as long-term memory activation: An individual-differences approach, Journal of Experimental Psychology: Learning, Memory and Cognition 19, 1101-1114.

Carhart, Mark M., 1997, On persistence in mutual fund performance, Journal of Finance 52, 5782.

Chapman, M., 1990, Cognitive development and the growth of capacity: Issues in neoPiagetian theory, in J. T. Enns (editor), The development of attention: Research and theory (Elsevier, Amsterdam), 263-287.

Coval, Joshua D., David Hirshleifer, and Tyler Shumway, 2002, Can individual investors beat the market?, Working Paper, University of Michigan.

Coval, Joshua D., and Tobias J. Moskowitz, 2001, The geography of investment: Informed trading and asset prices, Journal of Political Economy 109(4), 811-841.

Dempster, F. N., 1981, Memory span: Sources of individual and developmental difference, Psychological Bulletin 89, 63-100.

Fama, Eugene F., and Kenneth R. French, 1992, The cross section of expected returns, Journal of Finance 47, 427-465.

Fama, Eugene F., and Kenneth French, 1993, Common risk factors in the return on bonds and stocks, Journal of Financial Economics 33, 3-53.

Fama, Eugene F., and J. MacBeth, 1973, Risk, return, and equilibrium: Empirical tests, Journal of Political Economy 71, 607-636. 
French, Kenneth R., and James M. Poterba, 1991, Investor diversification and international equity markets, American Economic Review 81, 222-226.

Goetzmann, William and Kumar, Alok, 2001, Equity portfolio diversification, NBER Working Paper 8686.

Huberman, Gur, 2001, Familiarity breeds investment, Review of Financial Studies 14(3), 659680.

Ivković, Zoran and Scott Weisbenner, 2004, Local does as local is: Information content of the geography of individual investors' common stock Investments, Journal of Finance, forthcoming.

Just, M. A., and Carpenter, P. A., 1992, A capacity theory of comprehension: Individual differences in working memory, Psychological Review 99, 122-149.

Kacperczyk, Marcin, Clemens Sialm, and Lu Zheng, 2004, On the industry concentration of actively managed equity mutual funds, Journal of Finance, forthcoming.

Kelly, Morgan, 1995, All their eggs in one basket: Portfolio diversification of US households, Journal of Economic Behavior and Organization 27, 87-96.

Kennickell, Arthur B. and Martha Starr-McCluer, 1994, Changes in family finances from 1989 to 1992: Evidence from the Survey of Consumer Finances, Federal Reserve Bulletin 80, 861882.

Liang, Nellie and Scott Weisbenner, 2002, Investor behavior and the purchase of company stock in 401(k) plans - The importance of plan design. NBER Working Paper 9131.

Miller, G. A., 1956, The magical number seven, plus or minus two: some limits on our capacity for processing information, Psychological Review 63, 81-97.

Odean, Terry, 1998, Are investors reluctant to realize their losses?, Journal of Finance 53, 17751798.

Odean, Terry, 1999, Do investors trade too much?, American Economic Review 89 (5), 12791298.

Piaget, J., 1971, The theory of stages in cognitive development, in D. R. Green (editor), Measurement and Piaget (McGraw Hill, New York), 1-11.

Zhu, Ning, 2002, The local bias of individual investors, Working Paper, Yale School of Management. 
Table I: Summary Statistics of Distribution of Portfolio Value, Number of Stocks, and Herfindahl Index by Portfolio Size The table summarizes the distribution of portfolio values, the number of the stocks held, and the portfolio Herfindahl Index for households with portfolios of various sizes. The Herfindahl Index is defined as $H I_{h}=\sum\left(w_{h, i}\right)^{2}$ (where $w_{h, i}$ is the weight of stock $i$ held by household $h$ at time $t$ ). The table also reports the proportion of households holding only one stock and the proportion of portfolios invested in S\&P 500 and local stocks (i.e., stocks of corporations headquartered within 50 miles from the household).

\begin{tabular}{|c|c|c|c|c|c|c|c|c|c|}
\hline & \multicolumn{3}{|c|}{ All Households } & \multicolumn{3}{|c|}{ Portfolio at least $\$ 25,000$} & \multicolumn{3}{|c|}{ Portfolio at least $\$ 100,000$} \\
\hline & $\begin{array}{r}\text { Portfolio } \\
\text { Value (\$) } \\
\end{array}$ & $\begin{array}{l}\text { No. of } \\
\text { Stocks } \\
\end{array}$ & $\begin{array}{l}\text { Herf. } \\
\text { Index } \\
\end{array}$ & $\begin{array}{r}\text { Portfolio } \\
\text { Value (\$) } \\
\end{array}$ & $\begin{array}{l}\text { No. of } \\
\text { Stocks }\end{array}$ & $\begin{array}{r}\text { Herf. } \\
\text { Index }\end{array}$ & $\begin{array}{r}\text { Portfolio } \\
\text { Value }(\$) \\
\end{array}$ & $\begin{array}{l}\text { No. of } \\
\text { Stocks }\end{array}$ & $\begin{array}{r}\text { Herf. } \\
\text { Index } \\
\end{array}$ \\
\hline Mean & 45,604 & 3.9 & 0.62 & 119,130 & 7.0 & 0.43 & 322,035 & 11.7 & 0.33 \\
\hline (std. dev.) & $(234,902)$ & $(5.2)$ & $(0.33)$ & $(398,442)$ & $(7.7)$ & $(0.31)$ & $(744,697)$ & $(12.1)$ & $(0.30)$ \\
\hline \multicolumn{10}{|l|}{ Percentiles } \\
\hline $10^{\text {th }}$ & 2,243 & 1.0 & 0.18 & 28,425 & 1.0 & 0.11 & 110,250 & 2.0 & 0.07 \\
\hline $25^{\text {th }}$ & 5,750 & 1.0 & 0.33 & 35,018 & 3.0 & 0.18 & 130,538 & 4.0 & 0.11 \\
\hline $50^{\text {th }}$ & 13,865 & 2.0 & 0.56 & 53,492 & 5.0 & 0.32 & 184,000 & 9.0 & 0.21 \\
\hline $75^{\text {th }}$ & 34,700 & 5.0 & 1.00 & 103,441 & 9.0 & 0.61 & 313,677 & 16.0 & 0.46 \\
\hline $90^{\text {th }}$ & 86,625 & 8.0 & 1.00 & 228,187 & 14.0 & 1.00 & 588,900 & 24.0 & 0.93 \\
\hline $\begin{array}{l}\% \text { of HHs holding } \\
\text { one stock }\end{array}$ & & 33.1 & & & 13.0 & & & 7.5 & \\
\hline $\begin{array}{l}\% \text { of holdings in } \\
\text { S\&P } 500 \text { stocks }\end{array}$ & & 53.2 & & & 56.7 & & & 59.3 & \\
\hline $\begin{array}{l}\% \text { of holdings in } \\
\text { local stocks }\end{array}$ & & 14.7 & & & 13.1 & & & 11.1 & \\
\hline $\begin{array}{l}\% \text { of holdings in } \\
\text { non-S\&P 500, } \\
\text { local stocks }\end{array}$ & & 7.6 & & & 6.3 & & & 5.1 & \\
\hline \# HH-year obs. & & 268,734 & & & 88,836 & & & 23,073 & \\
\hline \# HH-stock-year obs. & & $1,046,282$ & & & 618,756 & & & 269,298 & \\
\hline
\end{tabular}




\section{Table II: Comparison of Stock Portfolio Size and Concentration in Sample with Survey of Consumer Finances}

The table presents a comparison between stock portfolio values and the number of stock holdings in the discount brokerage sample and the Survey of Consumer Finances (SCF) for households with various initial portfolio levels. The two reported comparisons are between the December 1992 sample and the 1992 SCF and between the November 1996 sample and the 1998 SCF. For direct comparison with the SCF, the table reports stock holdings only in taxable accounts for the brokerage house sample.

\begin{tabular}{|c|c|c|c|c|c|c|}
\hline \multicolumn{7}{|c|}{ Panel A: Comparison of 12/1992 Sample with 1992 Survey of Consumer Finances } \\
\hline & \multicolumn{2}{|c|}{ All Households } & \multicolumn{2}{|c|}{$\begin{array}{l}\text { Portfolio at least } \\
\$ 25,000\end{array}$} & \multicolumn{2}{|c|}{$\begin{array}{l}\text { Portfolio at least } \\
\$ 100,000\end{array}$} \\
\hline & Sample & SCF & Sample & SCF & Sample & SCF \\
\hline \multicolumn{7}{|l|}{ Portfolio Value (\$) } \\
\hline Mean & 44,707 & 66,810 & 116,503 & 213,145 & 304,076 & 465,515 \\
\hline $25^{\text {th }}$ percentile & 5,401 & 2,000 & 35,728 & 35,000 & 129,833 & 120,000 \\
\hline $50^{\text {th }}$ percentile & 13,869 & 8,000 & 54,475 & 70,000 & 181,355 & 181,000 \\
\hline $75^{\text {th }}$ percentile & 35,604 & 30,000 & 105,273 & 150,000 & 306,182 & 400,000 \\
\hline \multicolumn{7}{|l|}{ Number of Stocks } \\
\hline Mean & 4.3 & 4.0 & 7.7 & 8.6 & 12.8 & 12.4 \\
\hline $25^{\text {th }}$ percentile & 1.0 & 1.0 & 3.0 & 3.0 & 5.0 & 4.0 \\
\hline $50^{\text {th }}$ percentile & 3.0 & 2.0 & 5.0 & 6.0 & 9.0 & 10.0 \\
\hline $75^{\text {th }}$ percentile & 5.0 & 4.0 & 10.0 & 10.0 & 17.0 & 15.0 \\
\hline Percent hold one stock & 30.1 & 45.1 & 11.8 & 11.4 & 6.3 & 7.8 \\
\hline \multicolumn{7}{|c|}{ Panel B: Comparison of 11/1996 Sample with 1998 Survey of Consumer Finances } \\
\hline & \multicolumn{2}{|c|}{ All Households } & \multicolumn{2}{|c|}{$\begin{array}{l}\text { Portfolio at least } \\
\$ 25,000\end{array}$} & \multicolumn{2}{|c|}{$\begin{array}{l}\text { Portfolio at least } \\
\$ 100,000\end{array}$} \\
\hline & Sample & SCF & Sample & SCF & Sample & SCF \\
\hline \multicolumn{7}{|l|}{ Portfolio Value (\$) } \\
\hline Mean & 87,509 & 160,697 & 181,881 & 351,327 & 426,820 & 783,228 \\
\hline $25^{\text {th }}$ percentile & 6,344 & 4,000 & 39,295 & 45,000 & 141,037 & 150,000 \\
\hline $50^{\text {th }}$ percentile & 20,664 & 18,000 & 66,625 & 70,000 & 213,811 & 251,000 \\
\hline $75^{\text {th }}$ percentile & 59,613 & 63,000 & 147,406 & 175,000 & 399,576 & 600,000 \\
\hline \multicolumn{7}{|l|}{ Number of Stocks } \\
\hline Mean & 5.1 & 5.7 & 8.3 & 9.8 & 13.3 & 15.6 \\
\hline $25^{\text {th }}$ percentile & 1.0 & 1.0 & 3.0 & 3.0 & 5.0 & 4.0 \\
\hline $50^{\text {th }}$ percentile & 3.0 & 2.0 & 6.0 & 6.0 & 10.0 & 10.0 \\
\hline $75^{\text {th }}$ percentile & 6.0 & 6.0 & 10.0 & 11.0 & 17.0 & 20.0 \\
\hline Percent hold one stock & 28.6 & 33.8 & 10.1 & 13.3 & 5.1 & 7.5 \\
\hline
\end{tabular}




\section{Table III: Summary Statistics for Trades}

The table summarizes the characteristics of trades for households with various portfolio values at the end of the year preceding the transaction. The table reports the distribution of transaction sizes, the proportion of transactions of stocks belonging to the S\&P 500 Index, the proportion of trades in local stocks (i.e., stocks of corporations headquartered within a 50 miles radius from the location of the household), and the proportion of transactions of at least $\$ 10,000$. The last two rows report the performance of stocks following a transaction. Excess returns are computed by subtracting the appropriate Fama and French (1992) benchmark portfolios formed according to size deciles and book-to-market deciles from raw stock returns.

\begin{tabular}{|c|c|c|c|c|c|c|c|c|}
\hline & \multicolumn{2}{|c|}{ All Households } & \multicolumn{2}{|c|}{$\begin{array}{l}\text { Portfolio Less than } \\
\$ 25,000\end{array}$} & \multicolumn{2}{|c|}{$\begin{array}{l}\text { Portfolio at Least } \\
\$ 25,000\end{array}$} & \multicolumn{2}{|c|}{$\begin{array}{c}\text { Portfolio at Least } \\
\$ 100,000\end{array}$} \\
\hline & Buys & Sales & Buys & Sales & Buys & Sales & Buys & Sales \\
\hline Number of transactions & 640,070 & 552,832 & 248,067 & 207,436 & 392,003 & 345,396 & 180,304 & 155,375 \\
\hline \multicolumn{9}{|l|}{ Distribution of transactions } \\
\hline Mean $(\$)$ & 10,640 & 12,874 & 5,665 & 6,463 & 13,788 & 16,723 & 19,453 & 24,091 \\
\hline $25^{\text {th }}$ percentile $(\$)$ & 2,550 & 2,713 & 1,825 & 1,850 & 3,400 & 3,650 & 4,600 & 5,073 \\
\hline $50^{\text {th }}$ percentile $(\$)$ & 4,988 & 5,650 & 3,350 & 3,675 & 6,513 & 7,625 & 9,350 & 11,250 \\
\hline $75^{\text {th }}$ percentile $(\$)$ & 10,375 & 12,600 & 6,100 & 7,000 & 14,025 & 17,375 & 20,600 & 25,875 \\
\hline \multicolumn{9}{|l|}{ Composition of transactions } \\
\hline Percent S\&P 500 & 39.8 & 42.4 & 38.3 & 40.9 & 40.7 & 43.3 & 40.9 & 43.0 \\
\hline Percent local & 14.5 & 15.2 & 15.9 & 17.0 & 13.6 & 14.0 & 12.5 & 12.9 \\
\hline Percent at least $\$ 10,000$ & 26.2 & 31.5 & 12.2 & 15.6 & 35.0 & 41.1 & 47.4 & 54.0 \\
\hline \multicolumn{9}{|l|}{ Performance after transaction } \\
\hline $\begin{array}{l}\text { Excess return following year } \\
\text { (mean, in percent) }\end{array}$ & -1.6 & 0.2 & -2.1 & 0.4 & -1.4 & 0.1 & -0.9 & -0.0 \\
\hline $\begin{array}{l}\text { Excess return following year } \\
\text { (median, in percent) }\end{array}$ & -7.1 & -5.3 & -7.9 & -5.4 & -6.7 & -5.3 & -6.2 & -5.2 \\
\hline
\end{tabular}


Table IV: Characteristics of Household Portfolios and Yearly Stock Purchases by Portfolio Concentration, Estimated Differences Between Portfolios with Multiple Stocks and Portfolios with One Stock

The table summarizes the characteristics of the portfolio and the trades for households with various portfolio values at the end of the year preceding the transaction. For each subsample, the first column summarizes the average characteristics for households that initially hold more than one stock (i.e., the "Baseline") and the second column summarizes the differences between the average characteristics of concentrated and diversified households.

\begin{tabular}{|c|c|c|c|c|c|c|c|c|}
\hline & \multicolumn{2}{|c|}{ All Households } & \multirow{2}{*}{\multicolumn{2}{|c|}{$\begin{array}{l}\text { Portfolio }<\$ 25,000 \\
\text { Baseline Difference } \\
\text { (hold }>1 \text { (when hold } \\
\text { stock) one stock) }\end{array}$}} & \multirow{2}{*}{\multicolumn{2}{|c|}{ 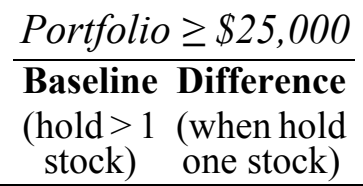 }} & \multicolumn{2}{|c|}{ Portfolio $\geq \$ 100,000$} \\
\hline & $\begin{array}{c}\text { Baseline } \\
\text { (hold }>1 \\
\text { stock) }\end{array}$ & $\begin{array}{l}\text { Difference } \\
\text { (when hold } \\
\text { one stock) }\end{array}$ & & & & & $\begin{array}{c}\text { Baseline } \\
\text { (hold > } 1 \\
\text { stock) }\end{array}$ & $\begin{array}{l}\text { Difference } \\
\text { (when hold } \\
\text { one stock) }\end{array}$ \\
\hline \multicolumn{9}{|c|}{ Panel A: Total Portfolio } \\
\hline$\%$ of HHs holding assets other than common stocks & 53.3 & $-19.8^{* * *}$ & 48.7 & $-13.3^{* * *}$ & 59.8 & $-38.9^{* * *}$ & 70.8 & $-49.0^{* * *}$ \\
\hline$\%$ of total assets not in common stocks & 18.3 & $2.1^{* * *}$ & $20 . .1$ & $2.3^{* * *}$ & 15.9 & $-8.7^{* * *}$ & 15.6 & $-10.7^{* * *}$ \\
\hline \multicolumn{9}{|c|}{ Panel B: Total Household-Level Stock Transactions During a Given Calendar Year } \\
\hline$\%$ of HHs with at least one stock purchase during year & 55.6 & $-23.1^{* * *}$ & 48.4 & $-16.1^{* * *}$ & 65.7 & $-31.5^{* * *}$ & 74.4 & $-35.4^{* * *}$ \\
\hline \# of buys per $\mathrm{HH}$ (mean) & 3.4 & $-2.3^{* * *}$ & 1.8 & $-0.8^{* * *}$ & 5.5 & $-3.7^{* * *}$ & 9.7 & $-6.5^{* * *}$ \\
\hline \# of buys conditional on at least one purchase (mean) & 6.1 & $-2.6^{* * *}$ & 3.8 & $-0.6^{* * *}$ & 8.4 & $-3.2^{* * *}$ & 13.0 & $-4.8^{* * *}$ \\
\hline Total buys conditional on purchase (median, \$) & 13,375 & $-3,575^{* * *}$ & 7,600 & $944^{* * *}$ & 27,509 & $8,191^{* * *}$ & 68,775 & 35,350 *** \\
\hline Total buys - total sales given purchase (median, $\$$ ) & 2,080 & $933^{* * *}$ & 2,025 & 1,056 & 2,250 & -338 & 3,496 & $-4,246^{* * *}$ \\
\hline \multicolumn{9}{|c|}{ Panel C: Individual Stock Purchases } \\
\hline Amount per purchase (median, \$) & 4,937 & 373 & 3,000 & $1,525^{* * *}$ & 6,325 & $8,869^{* * *}$ & 9,128 & $18,622^{* * *}$ \\
\hline$\%$ S\&P 500 & 39.8 & 0.0 & 37.9 & $1.4^{* * *}$ & 40.7 & 1.2 & 40.8 & 3.0 \\
\hline$\%$ Local & 13.7 & $5.1^{* * *}$ & 14.9 & $3.5^{* * *}$ & 13.1 & $7.6^{* * *}$ & 12.0 & $12.5^{* * *}$ \\
\hline$\%$ Non-S\&P 500, Local & 9.1 & $3.4^{* * *}$ & 10.1 & $2.2^{* * *}$ & 8.6 & $4.8^{* * *}$ & 7.8 & $9.2^{* * *}$ \\
\hline
\end{tabular}

, , denote significance at the 1 percent, 5 percent, and 10 percent levels, respectively. 
Table V: Relating One-Year Stock Returns Following Purchase or Sale to Household Portfolio Concentration at Prior-Year End

The table reports the estimates of regression specifications relating returns and concentration levels. Panels A and B report results based on specifications from Equations 2 and 3, estimated separately for purchases and sales. Panel $\mathrm{C}$ reports estimates based on all trades: $R_{i, h, t+1}$ to $t+12=\alpha+\beta_{0} B U Y_{i, h, t}+\beta_{1} H I_{h, y-1}+\beta_{2} B U Y_{i, h, t} H I_{h, y-1}+\varepsilon_{i, h, t+1}$ to $t+12$ (Equation 4) and $X_{i, h, t+1}$ to $t+12=\beta_{0} B U Y_{i, h, t}+\beta_{1} H I_{h, y-1}+$ $\beta_{2} B U Y_{i, h, t} H I_{h, y-1}+\gamma \boldsymbol{I}_{i, t}+\delta \boldsymbol{I}_{t} R_{i, h, t-12 \text { to } t}+\varepsilon_{i, h, t+1}$ to $t+12$ (Equation 5). The dependent variable is either the raw or the excess return of stock $i$ purchased or sold by household $h$ at time $t$ during the subsequent year $\left(R_{i, h, t+1}\right.$ to $t+12$ and $X_{i, h, t+1}$ to $t+12$, respectively). The excess returns are computed by subtracting the appropriate Fama and French (1992) benchmark portfolios formed according to size deciles and book-tomarket deciles from the raw stock returns. Specifications from Equations 3 and 5 include $\boldsymbol{I I}_{\boldsymbol{i}, \boldsymbol{t}}$, the interaction terms between the two-digit SIC codes and indicator variables for the 71 months during which a transaction could occur, and momentum effects, measured by the return

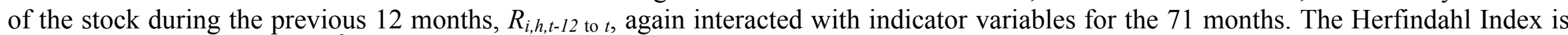
defined as $H I_{h, y-1}=\sum\left(w_{h, i, y-1}\right)^{2}$ ( $w_{h, i, y-1}$ is the weight of stock $i$ held by household $h$ at the end of the year preceding the year in which the transaction took place). The indicator variable $B U Y_{i, h, t}$ captures whether a transaction was a buy transaction. The standard errors, given in parentheses, take into account heteroskedasticity and cross-sectional correlation. All the returns are expressed in percentage points. 
Table V: Continued

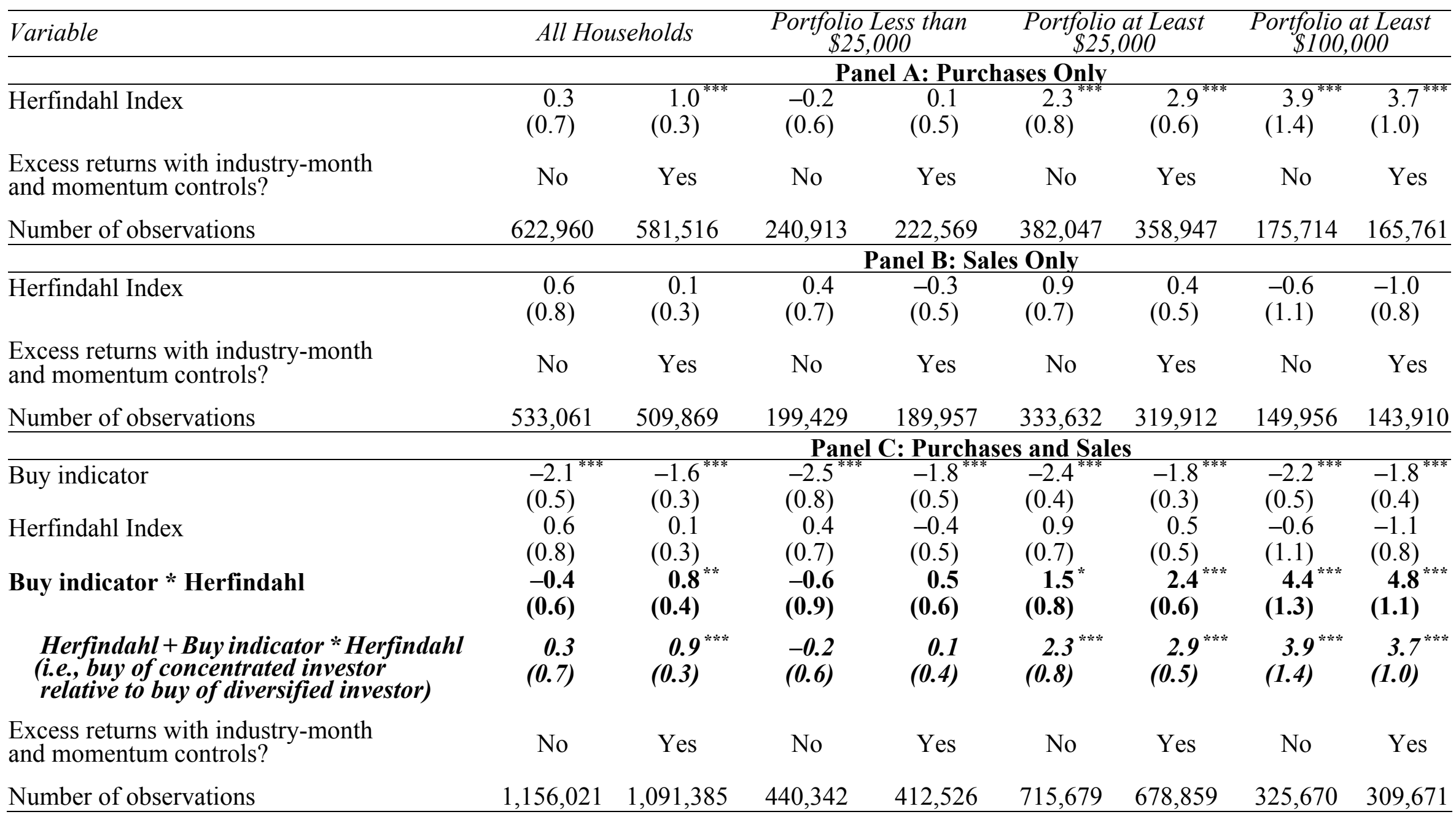

${ }^{* * *},{ }^{* *},{ }^{*}$ denote significance at the 1 percent, 5 percent, and 10 percent levels, respectively. 


\section{Table VI: Relating One-Year Stock Returns Following Purchase or Sale to Household Portfolio Concentration at Prior-Year End, Inclusion of Household Fixed Effects}

The table reports the estimates of the fixed-effects regression specification based on Equations 2 through 5. The variables and the underlying specifications are the same as in Table V. The only difference is the inclusion of fixed effects. For example, fixed effects are incorporated into Equations 4 and 5 to produce Equations 6 and 7, respectively:

$$
\begin{aligned}
& R_{i, h, t+1} \text { to } t+12=\beta_{1} H I_{h, y-1}+\beta_{2} B U Y_{i, h, t} H I_{h, y-1}+\mu I_{h} B U Y_{h}+\eta I_{h} S E L L_{h}+\varepsilon_{i, h, t+1} \text { to } t+12 \\
& X_{i, h, t+1} \text { to } t+12=\beta_{1} H I_{h, y-1}+\beta_{2} B U Y_{i, h, t} H I_{h, y-1}+\gamma I_{i, t}+\delta I_{t} R_{i, h, t-12 \text { to } t}+\mu I_{h} B U Y_{h}+\eta I_{h} S E L L_{h}+\varepsilon_{i, h, t+l \text { to } t+12}
\end{aligned}
$$

The dependent variables are the raw return and the excess return of stock $i$ purchased or sold by household $h$ at time $t$ during the subsequent year $\left(R_{i, h, t+1}\right.$ to $t+12$ and $X_{i, h, t+1}$ to $t+12$, respectively). $I_{h} B U Y_{h}$ and $I_{h} S E L L_{h}$ denote that separate household fixed effects are included for buys and sales, thus controlling for the average stock-picking ability (both for purchases and sales) of the household. The indicator variable $B U Y_{i, h, t}$ captures whether a transaction was a buy transaction. The buy indicator variable is not included in the regression by itself, as it is absorbed in the household fixed effects. The standard errors are given in parentheses and take into account heteroskedasticity and cross-sectional correlation. The full sample consists of 52,661 households. All the returns are expressed in percentage points.

\section{Variable}

Herfindahl Index

Excess returns with industry-month and momentum controls?

Number of observations

Herfindahl Index

Excess returns with industry-month and momentum controls?

Number of observations

Buy indicator

Herfindahl Index

\section{Buy indicator * Herfindahl}

\section{Herfindahl + Buy indicator $*$ Herfindahl (i.e., buy of concentrated investor minus buy of diversified investor)}

Excess returns with industry-month and momentum controls?

Number of observations ***,
Without Fixed Effects

With Fixed Effects for Purchases \& sales

0.3

$(0.7)$

No

622,960

622,960

(0.8)

$(0.3)$

No

Yes

533,061 509,869 $-1.6^{*}$

0.6

(0.8)

$-0.4$

(0.6)

(0.3)

0.1

$(0.3)$

0.8 ***

(0.4)

\section{3}

(0.7)

$(0.3)$

No

Yes

$1,156,021 \quad 1,091,385$

$,{ }^{* *},{ }^{*}$ denote significance at the 1 percent, 5 percent, and 10 percent levels, respectively. 


\section{Table VII: One-Year Excess Returns Following Transactions, Differential Between Purchases and Sales, Interaction with S\&P 500 Status and Locality of Stock}

The table reports the estimates of the regression specification relating returns and concentration levels: $X_{i, h, t+1}$ to $t+12=\beta_{0} B U Y_{i, h, t}+$ $\beta_{1} H I_{h, y-1}+\beta_{2} B U Y_{i, h, t} H I_{h, y-1}+\gamma I_{i, t}+\delta I_{t} R_{i, h, t-12 \text { to } t}+\varepsilon_{i, h, t+1}$ to $t+12$ (Equation 5). The dependent variable is the excess return of stock $i$ purchased or sold by household $h$ at time $t$ during the subsequent year $\left(X_{i, h, t+1}\right.$ to $\left.t+12\right)$. The excess returns are computed by subtracting the appropriate Fama and French (1992) benchmark portfolios formed according to size deciles and book-to-market deciles from the raw stock returns. The specification also includes $I I_{i, t}$, the interaction terms between the two-digit SIC codes and indicator variables for the 71 months during which a transaction could occur, and momentum effects, measured by the return of the stock during the previous

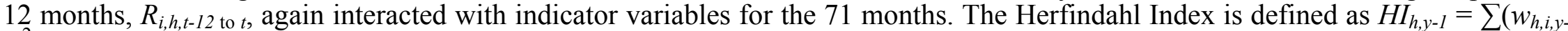
$\left.{ }_{1}\right)^{2}\left(w_{h, i, y-l}\right.$ is the weight of stock $i$ held by household $h$ at the end of the year preceding the year in which the transaction took place). The indicator variable $B U Y_{i, h, t}$ captures whether a transaction was a buy transaction. The difference between one-year excess returns following purchases and excess returns following sales is $\left(\beta_{0}+\beta_{2}\right)$ for perfectly concentrated households and $\beta_{0}$ for perfectly diversified households, yielding a difference in the buy/sale differential return across perfectly concentrated and diversified households of $\beta_{2}$ (shown in the table). The difference in differential returns (i.e., the return to concentration) is reported for various samples of transactions formed on the basis of the stock's S\&P 500 status and the locality to the investor. Stocks headquartered within 50 miles of the investor are classified as local stocks. The standard errors, given in parentheses, take into account heteroskedasticity and cross-sectional correlation. All the returns are expressed in percentage points.

\begin{tabular}{|c|c|c|c|c|c|c|c|c|c|}
\hline Sample & $\begin{array}{l}\text { All Stocks } \\
\text { (given know } \\
\text { HH Location) }\end{array}$ & S\&P 500 & Non-S\&P 500 & Local & Non-Local & $\begin{array}{l}\text { S\&P 500, } \\
\text { Local }\end{array}$ & $\begin{array}{c}\text { S\&P 500, } \\
\text { Non-Local }\end{array}$ & $\begin{array}{c}\text { Non-S\&P 500, } \\
\text { Local }\end{array}$ & $\begin{array}{l}\text { Non-S\&P 500, } \\
\text { Non-Local }\end{array}$ \\
\hline All Households & $(0.5)$ & $\begin{array}{r}0.4 \\
(0.5)\end{array}$ & $\begin{array}{l}2.4^{* * *} \\
(0.8)\end{array}$ & $\begin{array}{l}5.0^{* * *} \\
(1.5)\end{array}$ & $\begin{array}{r}0.8 \\
(0.5)\end{array}$ & $\begin{array}{r}1.3 \\
(1.1)\end{array}$ & $\begin{array}{r}0.0 \\
(0.5)\end{array}$ & $\begin{array}{l}6.9^{* * *} \\
(2.3)^{-1}\end{array}$ & $(0.8)^{1.7^{* *}}$ \\
\hline $\begin{array}{l}\text { Portfolio Less } \\
\text { than } \$ 25,000\end{array}$ & $\begin{array}{r}1.1 \\
(0.8)\end{array}$ & $\begin{array}{l}-0.1 \\
(0.6)\end{array}$ & $\begin{array}{r}2.0 \\
(1.2)\end{array}$ & $\begin{array}{c}4.3^{* *} \\
(2.0)\end{array}$ & $\begin{array}{r}0.7 \\
(0.7)\end{array}$ & $\begin{array}{r}2.4 \\
(2.0)\end{array}$ & $\begin{array}{l}-0.7 \\
(0.6)\end{array}$ & $\begin{array}{r}4.7 \\
(3.0)\end{array}$ & $\begin{array}{r}1.8 \\
(1.2)\end{array}$ \\
\hline $\begin{array}{l}\text { Portfolio at } \\
\text { Least } \$ 25,000\end{array}$ & $\begin{array}{l}3.2^{* * *} \\
(0.8)\end{array}$ & $\begin{array}{l}1.3^{*} \\
(0.7)\end{array}$ & $\begin{array}{l}4.8^{* * *} \\
(1.4)\end{array}$ & $\begin{array}{l}8.6^{* * *} \\
(3.1)\end{array}$ & ${ }^{2.1}{ }^{* * *}$ & $\begin{array}{r}1.9 \\
(2.0)\end{array}$ & $(0.7)$ & $\begin{array}{l}13.0 \text { *** } \\
(5.0)\end{array}$ & ${ }^{3.0^{* *}}$ \\
\hline $\begin{array}{l}\text { Portfolio at } \\
\text { Least } \$ 100,000\end{array}$ & $(1.5)^{5.7^{* * *}}$ & $\begin{array}{r}1.2 \\
(1.0)\end{array}$ & $\begin{array}{l}9.5^{* * *} \\
(2.7)^{2}\end{array}$ & $\begin{array}{l}11.6^{*} \\
(6.8)\end{array}$ & $\begin{array}{l}4.5^{* * *} \\
(1.5)^{-1}\end{array}$ & $\begin{array}{l}-1.1 \\
(3.2)\end{array}$ & $\begin{array}{r}1.6 \\
(1.0)\end{array}$ & $\begin{array}{c}18.0^{*} \\
(10.2)\end{array}$ & ${ }^{7.44^{* * *}}$ \\
\hline
\end{tabular}

*** $, \quad{ }^{* *},{ }^{*}$ denote significance at the 1 percent, 5 percent, and 10 percent levels, respectively. 


\section{Table VIII: Sensitivity of Return to Concentration to Specific Stocks and Non-Stock Holdings}

The table reports the estimates of the regression specification relating returns and concentration levels: $X_{i, h, t+1}$ to $t+12=\beta_{0} B U Y_{i, h, t}+\beta_{1} H I_{h, y-1}+\beta_{2} B U Y_{i, h, t} H I_{h, y-1}+\gamma \boldsymbol{I}_{i, t}+\delta \boldsymbol{I}_{\boldsymbol{t}} R_{i, h, t-12 \text { to } t}+\varepsilon_{i, h, t+1}$ to $t+12$ (Equation $5)$. The dependent variable is the excess return of stock $i$ purchased or sold by household $h$ at time $t$ during the subsequent year $\left(X_{i, h, t+1}\right.$ to $\left.t+12\right)$. The excess returns are computed by subtracting the appropriate Fama and French (1992) benchmark portfolios formed according to size deciles and bookto-market deciles from the raw stock returns. The specification also includes $I I_{i, t}$, the interaction terms between the two-digit SIC codes and indicator variables for the 71 months during which a transaction could occur, and momentum effects, measured by the return of the stock during the previous 12

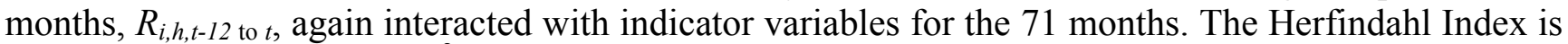
defined as $H I_{h, y-1}=\sum\left(w_{h, i, y-1}\right)^{2}$ ( $w_{h, i, y-1}$ is the weight of stock $i$ held by household $h$ at the end of the year preceding the year in which the transaction took place). The indicator variable $B U Y_{i, h, t}$ captures whether a transaction was a buy transaction. The difference between one-year excess returns following purchases and excess returns following sales is $\left(\beta_{0}+\beta_{2}\right)$ for perfectly concentrated households and $\beta_{0}$ for perfectly diversified households, yielding a difference in the buy/sale differential return across perfectly concentrated and diversified households of $\beta_{2}$ (i.e., the return to concentration), shown in the table for various subsamples. The first row displays differential returns for the full sample. The next three rows feature differential returns for the subsamples that exclude stocks according to three criteria: largest transactions, largest (smallest) subsequent returns, and largest number of transactions. The last two rows present differential returns for the subsamples of households that hold, or do not hold, assets other than common stocks. The standard errors, given in parentheses, take into account heteroskedasticity and cross-sectional correlation. All the returns are expressed in percentage points.

\begin{tabular}{|c|c|c|c|c|}
\hline Sample & $\begin{array}{c}\text { All } \\
\text { Households }\end{array}$ & $\begin{array}{l}\text { Portfolio Less } \\
\text { than } \$ 25,000\end{array}$ & $\begin{array}{l}\text { Portfolio at } \\
\text { Least } \$ 25,000\end{array}$ & $\begin{array}{c}\text { Portfolio at } \\
\text { Least } \$ 100,000\end{array}$ \\
\hline (1) Full Sample & $\begin{array}{l}0.8^{* *} \\
(0.4)\end{array}$ & $\begin{array}{r}0.5 \\
(0.6)\end{array}$ & $\begin{array}{l}2.4^{* * * *} \\
(0.6)\end{array}$ & $4^{4.8^{* * * *}}$ \\
\hline $\begin{array}{l}\text { (2) Replace stock's excess return with } \\
\text { market return }\end{array}$ & $\begin{array}{l}-0.3^{* * *} \\
(0.1)\end{array}$ & $\begin{array}{l}-0.6^{* * *} \\
(0.1)\end{array}$ & $\begin{array}{l}-0.3^{* *} \\
(0.1)\end{array}$ & $\begin{array}{l}-0.3 \\
(0.2)\end{array}$ \\
\hline $\begin{array}{l}\text { (3) Replace stock's excess return with } \\
\text { appropriate portfolio return }\end{array}$ & $\begin{array}{l}-0.4^{* * *} \\
(0.1)\end{array}$ & $\begin{array}{l}-0.6^{* * *} \\
(0.2)\end{array}$ & $\begin{array}{l}-0.5^{* *} \\
(0.2)\end{array}$ & $\begin{array}{l}-0.5 \\
(0.3)\end{array}$ \\
\hline $\begin{array}{l}\text { (4) Exclude stock(s) that had the largest } \\
\text { (in \$) purchase and/or sale }\end{array}$ & $\begin{array}{r}0.2 \\
(0.4)\end{array}$ & $\begin{array}{r}1.0 \\
(0.6)\end{array}$ & $(0.7)^{* * *}$ & $(1.3)^{3 *}$ \\
\hline $\begin{array}{l}\text { (5) Exclude stock(s) that had the largest } \\
\text { (smallest) return purchase (sale) }\end{array}$ & $\begin{array}{r}0.2 \\
(0.4)\end{array}$ & $\begin{array}{r}0.6 \\
(0.6)\end{array}$ & $(0.6)$ & $\begin{array}{l}3.8^{* * *} \\
(1.0)\end{array}$ \\
\hline $\begin{array}{l}\text { (6) Exclude stock(s) that had the largest } \\
\text { number of purchases and/or sales }\end{array}$ & $\begin{array}{r}0.3 \\
(0.5)\end{array}$ & $\begin{array}{r}0.6 \\
(0.9)\end{array}$ & $(0.8)$ & $\begin{array}{l}4.0^{* * *} \\
(1.4)^{-}\end{array}$ \\
\hline $\begin{array}{l}\text { (7) Household holds assets other than } \\
\text { common stocks (e.g., mutual funds) }\end{array}$ & $\begin{array}{l}-0.1 \\
(0.5)\end{array}$ & $\begin{array}{r}0.5 \\
(0.8)\end{array}$ & $\begin{array}{r}0.8 \\
(0.8)\end{array}$ & $\begin{array}{l}3.5^{* * *} \\
(1.4)\end{array}$ \\
\hline (8) Household holds only common stocks & ${ }^{2.11^{* * *}}$ & $\begin{array}{r}0.6 \\
(1.0)\end{array}$ & $\begin{array}{l}4.6^{* * *} \\
(0.9)\end{array}$ & ${ }^{7.2^{* * *}}$ \\
\hline
\end{tabular}

${ }^{* * * *},{ }^{* *},{ }^{*}$ denote significance at the 1 percent, 5 percent, and 10 percent levels, respectively. 


\section{Table IX: Relating Stock Returns at Various Horizons Following Purchase or Sale to \\ Household Portfolio Concentration at Prior-Year End}

The table reports the estimates of two regression specifications relating returns and concentration levels: $R_{i, h, t}$ to $t+\Delta t=\alpha+\beta_{0} B U Y_{i, h, t}+$ $\beta_{1} H I_{h, y-1}+\beta_{2} B U Y_{i, h, t} H I_{h, y-1}+\varepsilon_{i, h, t}$ to $t^{+} \Delta t$ (Equation 4) and $X_{i, h t}$ to $t^{+} \Delta t=\beta_{0} B U Y_{i, h, t}+\beta_{1} H I_{h, y-1}+\beta_{2} B U Y_{i, h, t} H I_{h, y-1}+\gamma \boldsymbol{I}_{i, t}+\delta \boldsymbol{I}_{t} R_{i, h, t-12 \text { to } t}+\varepsilon_{i, h, t}$ to $t+\Delta t$ (Equation 5). The dependent variable is either the raw return of stock $i$ purchased or sold by household $h$ at time $t$ during the subsequent time interval $\Delta t\left(R_{i, h, t}\right.$ to $\left.t+\Delta t\right)$, or the excess return of stock $i$ purchased or sold by household $h$ at time $t$ during the subsequent time interval $\Delta t$ $\left(X_{i, h, t}\right.$ to $\left.t_{+} \Delta t\right)$. The time intervals we consider are one week, one month, three months, six months, and one year since purchase. The excess returns are computed by subtracting the appropriate Fama and French (1992) benchmark portfolios formed according to two size and three book-to-market groupings from the raw stock returns. The second specification includes $\boldsymbol{I I}_{\boldsymbol{i}, \boldsymbol{t}}$, the interaction terms between the two-digit SIC codes and indicator variables for the individual trading days during which a transaction could occur, and momentum effects, measured by the return of the stock during the previous 12 months, $R_{i, h, t-12}$ to $t$, interacted with indicator variables for the 71 months in the sample. The Herfindahl Index is defined as $H I_{h, y-1}=\sum\left(w_{h, i, y-1}\right)^{2}\left(w_{h, i, y-1}\right.$ is the weight of stock $i$ held by household $h$ at the end of the year preceding the year in which the transaction took place). The indicator variable $B U Y_{i, h, t}$ captures whether a transaction was a buy transaction. The standard errors, given in parentheses, take into account heteroskedasticity and cross-sectional correlation. All the returns are expressed in percentage points.

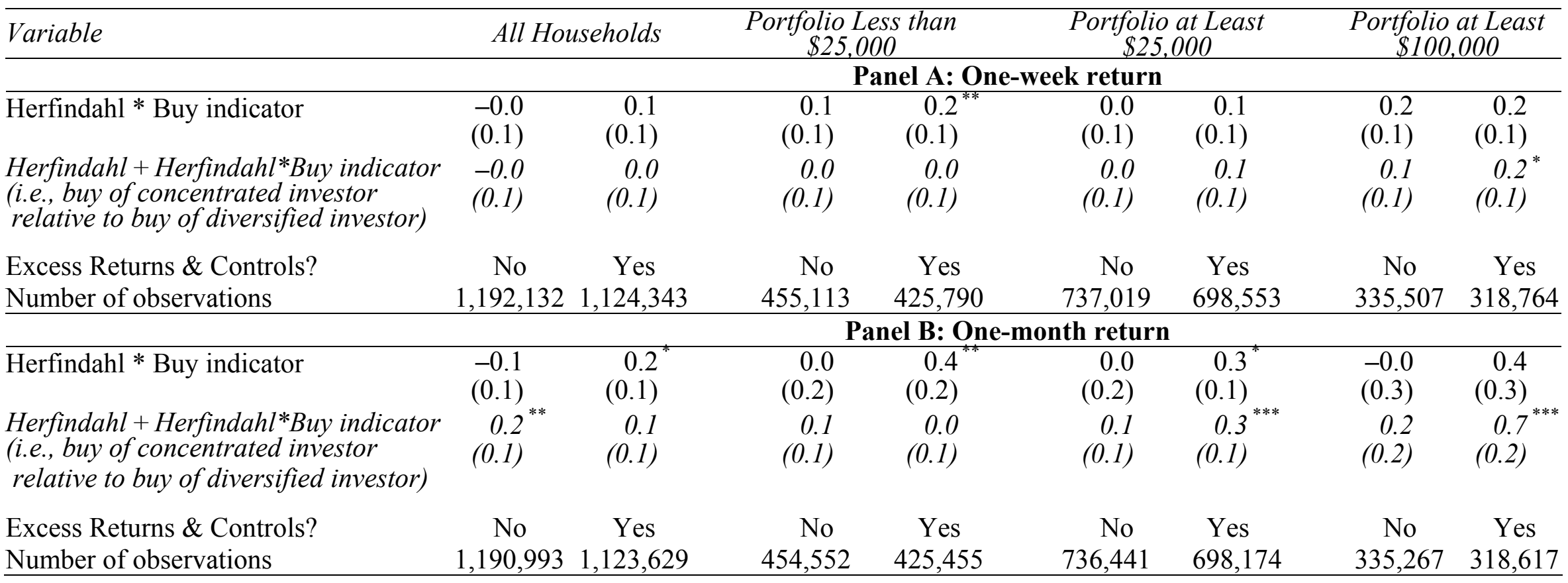

${ }^{* * *},{ }^{* *},{ }^{*}$ denote significance at the 1 percent, 5 percent, and 10 percent levels, respectively. 
Table IX: Continued

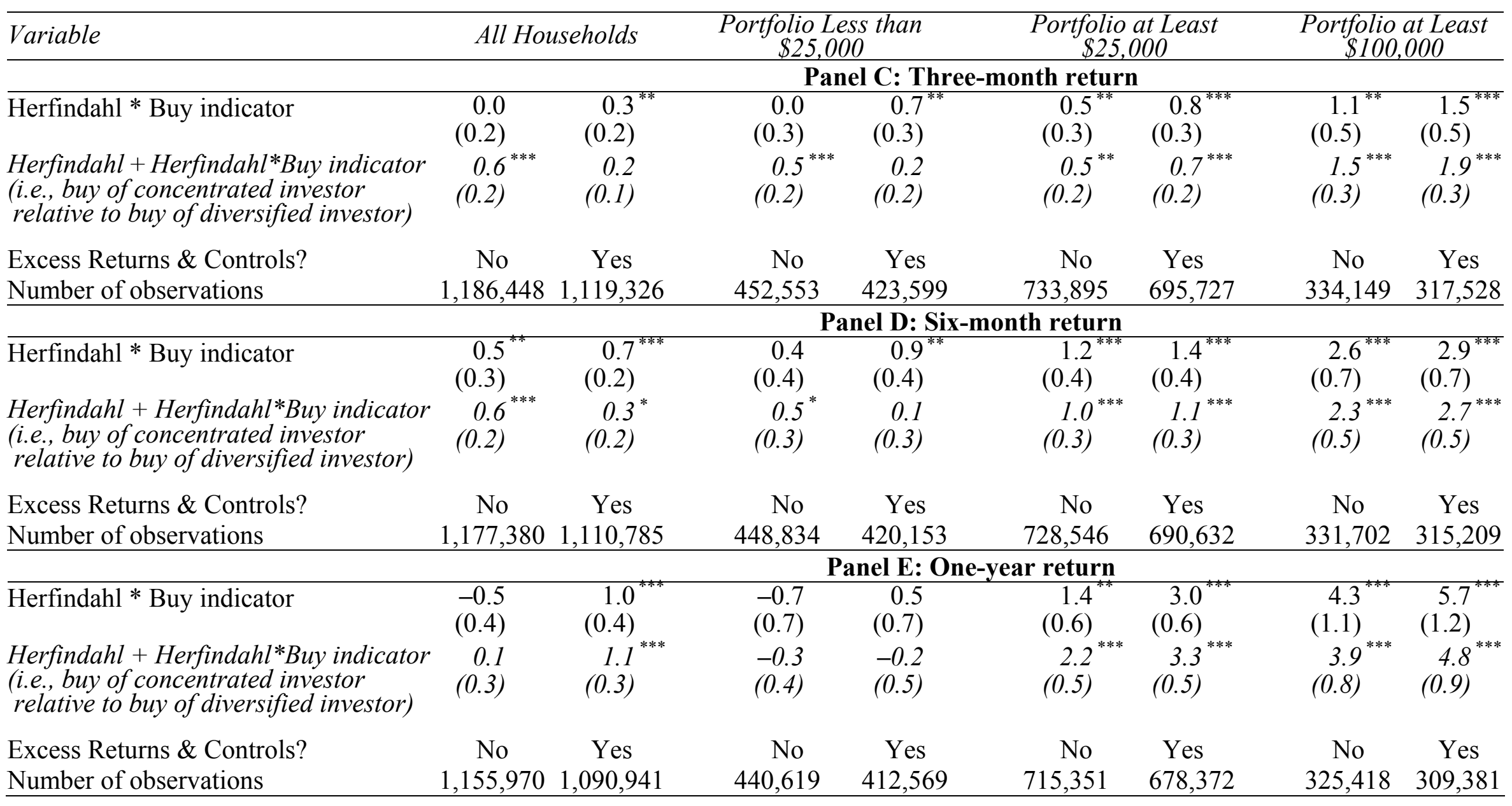

${ }^{* * *},{ }^{* *},{ }^{*}$ denote significance at the 1 percent, 5 percent, and 10 percent levels, respectively. 
Table X: Monthly Portfolio Returns Measuring the Differential in

Performance of Trades between Concentrated and Diversified Households

The average raw return per month and the abnormal return per month (Alpha) from various portfolios over the period from February 1991 to November 1997 are expressed in percentage points. Abnormal monthly returns are calculated from a four-factor model, which accounts for the market, size, book-to-market, and momentum effects (Carhart (1997)). The loadings on the four factors are not displayed in the table. We aggregate the trades made by concentrated and diversified investors into portfolios to test whether the trades (return following purchases minus return following sales) made by concentrated households outperform those placed by diversified households. For various subsamples - trades in all stocks, trades in stocks classified according to their S\&P 500 Index membership status, trades in stocks characterized by the distance between the household and the corporate headquarters, as well as the interactions of the latter two criteriawe form zero-cost portfolios and evaluate their performance. A stock is defined to be local to the household if the firm is headquartered within 50 miles of the household. The long side of each zero-cost portfolio is itself a zero-cost portfolio wherein all the stock purchases (sales) made by concentrated households are on its long (short) side. The short side, quite analogously, again is itself a zero-cost portfolio wherein all the stock purchases (sales) made by diversified households are on its long (short) side. We define a concentrated investor as one with a portfolio Herfindahl Index of at least 0.5 at the prior year-end. A stock transaction is kept in the appropriate portfolio (buy/sale, concentrated/diversified) for 12 months, starting with the first full calendar month after the transaction, with the aggregated transactions weighted by the amount of the transaction. The top panel focuses on portfolios formed with stock trades made by all households. The bottom panel focuses on portfolios formed with stock trades made by households with stock portfolios of at least $\$ 100,000$ at the prior year-end. Standard errors incorporate the Newey-West correction with autocorrelation up to three lags.

\begin{tabular}{|c|c|c|c|c|c|c|c|c|c|}
\hline & All Stocks & S\&P 500 & Non-S\&P 500 & Local & Non-Local & $\begin{array}{l}\text { S\&P 500, } \\
\text { Local }\end{array}$ & $\begin{array}{l}\text { S\&P 500, } \\
\text { Non-Local }\end{array}$ & $\begin{array}{l}\text { Non-S\&P 500, } \\
\text { Local }\end{array}$ & $\begin{array}{l}\text { Non-S\&P 500, } \\
\text { Non-Local }\end{array}$ \\
\hline \multicolumn{10}{|c|}{ Panel A: All Households } \\
\hline Raw Returns & $\begin{array}{c}0.08^{*} \\
(0.04)\end{array}$ & $\begin{array}{r}0.05 \\
(0.04)\end{array}$ & $\begin{array}{c}0.14^{* *} \\
(0.07)\end{array}$ & $\begin{array}{r}0.22 \\
(0.17)\end{array}$ & $\begin{array}{r}0.04 \\
(0.03)\end{array}$ & $\begin{array}{r}0.02 \\
(0.17)\end{array}$ & $\begin{array}{r}0.05 \\
(0.04)\end{array}$ & $\begin{array}{r}0.41 \\
(0.21)\end{array}$ & $\begin{array}{r}0.08 \\
(0.06)\end{array}$ \\
\hline Alpha & $\begin{array}{r}0.07^{*} \\
(0.04)\end{array}$ & $\begin{array}{r}0.05 \\
(0.05)\end{array}$ & $\begin{array}{c}0.13^{*} \\
(0.07)\end{array}$ & $\begin{array}{c}0.30^{*} \\
(0.16)\end{array}$ & $\begin{array}{r}0.03 \\
(0.04)\end{array}$ & $\begin{array}{r}0.10 \\
(0.17)\end{array}$ & $\begin{array}{r}0.04 \\
(0.05)\end{array}$ & $\begin{array}{c}0.59^{* * *} \\
(0.18)\end{array}$ & $\begin{array}{r}0.06 \\
(0.05)\end{array}$ \\
\hline \multicolumn{10}{|c|}{ Panel B: Household Portfolio \$100,000+ } \\
\hline Raw Returns & $\begin{array}{l}0.22^{* * *} \\
(0.07)\end{array}$ & $\begin{array}{c}0.17^{*} \\
(0.09)\end{array}$ & $\begin{array}{l}0.41^{* * *} \\
(0.13)\end{array}$ & $\begin{array}{c}0.53^{* *} \\
(0.26)\end{array}$ & $\begin{array}{r}0.13 \\
(0.09)\end{array}$ & $\begin{array}{r}0.11 \\
(0.37)\end{array}$ & $\begin{array}{r}0.08 \\
(0.09)\end{array}$ & $\begin{array}{c}0.63^{* *} \\
(0.30)\end{array}$ & $\begin{array}{r}0.21 \\
(0.16)\end{array}$ \\
\hline Alpha & $\begin{array}{c}0.23^{* *} \\
(0.10)\end{array}$ & $\begin{array}{r}0.13 \\
(0.08)\end{array}$ & $\begin{array}{c}0.42^{* *} \\
(0.17)\end{array}$ & $\begin{array}{c}0.49^{*} \\
(0.30)\end{array}$ & $\begin{array}{r}0.09 \\
(0.08)\end{array}$ & $\begin{array}{l}-0.46 \\
(0.50)\end{array}$ & $\begin{array}{r}0.02 \\
(0.10)\end{array}$ & $\begin{array}{c}0.89^{* * *} \\
(0.34)\end{array}$ & $\begin{array}{r}0.21 \\
(0.13)\end{array}$ \\
\hline
\end{tabular}

*** $,{ }^{* *},{ }^{*}$ denote significance at the 1 percent, 5 percent, and 10 percent levels, respectively. 


\section{Table XI: Excess Monthly Portfolio Returns, Concentrated vs. Not Concentrated Holdings, \\ by Investment Type (S\&P 500 status interacted with locality)}

The average abnormal return per month (Alpha) from various portfolios over the period from February 1991 to December 1996 is expressed in percentage points. Abnormal monthly returns are calculated from a four-factor model, which accounts for the market, size, book-to-market, and momentum effects (Carhart (1997)). The loadings on the four factors are not displayed in the table. Concentrated investments are the stocks held by households that hold only two or fewer stocks (two stocks is the median sample ownership across all households). The alpha for concentrated investments in the universe of all stocks is the excess return on investments held by households that hold only one or two stocks weighted across all such household portfolios, while the alpha for not-concentrated investments in the universe of all stocks is the excess return on investments held by households that hold more than two stocks, weighted across all such household portfolios. The alpha for concentrated investments in S\&P 500 stocks is the abnormal return on S\&P 500 stocks held by concentrated investors, weighted across all such households, while the alpha for not-concentrated investments in all S\&P 500 stocks is the abnormal return on S\&P 500 investments held by households that hold more than two stocks, weighted across all such stock positions. The alphas for concentrated and not concentrated investments are defined analogously for the other categories of stocks (e.g., local, non-S\&P 500 and local, etc.). A stock is defined to be local to the household if the firm is headquartered within 50 miles of the household. The holdings are kept in the portfolio for one month, after which time the portfolio is updated with the households' stock holdings at the end of the next month. The top panel focuses on portfolios formed with stocks held by all households. The bottom panel focuses on portfolios formed with stocks held by households with stock portfolios of at least $\$ 100,000$. Standard errors incorporate the Newey-West correction with autocorrelation up to three lags.

\begin{tabular}{|c|c|c|c|c|c|c|c|c|c|}
\hline & All Stocks & S\&P 500 & Non-S\&P 500 & Local & Non-Local & $\begin{array}{l}\text { S\&P 500, } \\
\text { Local }\end{array}$ & $\begin{array}{l}\text { S\&P 500, } \\
\text { Non-Local }\end{array}$ & $\begin{array}{l}\text { Non-S\&P 500, } \\
\text { Local }\end{array}$ & $\begin{array}{l}\text { Non-S\&P 500, } \\
\text { Non-Local }\end{array}$ \\
\hline \multicolumn{10}{|c|}{ Panel A: All Households } \\
\hline $\begin{array}{l}\text { Alpha, } \\
\text { Concentrated }\end{array}$ & $\begin{array}{r}0.15 \\
(0.13)\end{array}$ & $\begin{array}{r}0.21 \\
(0.13)\end{array}$ & $\begin{array}{r}0.19 \\
(0.22)\end{array}$ & $\begin{array}{c}0.39^{*} \\
(0.21)\end{array}$ & $\begin{array}{r}0.13 \\
(0.15)\end{array}$ & $\begin{array}{r}0.23 \\
(0.17)\end{array}$ & $\begin{array}{r}0.21 \\
(0.14)\end{array}$ & $\begin{array}{r}0.64 \\
(0.42)\end{array}$ & $\begin{array}{l}-0.01 \\
(0.26)\end{array}$ \\
\hline $\begin{array}{l}\text { Alpha, Not } \\
\text { Concentrated }\end{array}$ & $\begin{array}{l}-0.01 \\
(0.08)\end{array}$ & $\begin{array}{c}0.17^{* *} \\
(0.09)\end{array}$ & $\begin{array}{l}-0.31^{*} \\
(0.17)\end{array}$ & $\begin{array}{r}0.05 \\
(0.13)\end{array}$ & $\begin{array}{l}-0.00 \\
(0.08)\end{array}$ & $\begin{array}{l}0.23^{* *} \\
(0.12)\end{array}$ & $\begin{array}{c}0.15^{*} \\
(0.08)\end{array}$ & $\begin{array}{l}-0.21 \\
(0.23)\end{array}$ & $\begin{array}{l}-0.31^{* *} \\
(0.16)\end{array}$ \\
\hline Difference & $\begin{array}{c}0.16 * \\
(0.09)\end{array}$ & $\begin{array}{r}0.04 \\
(\mathbf{0 . 0 8})\end{array}$ & $\begin{array}{l}0.50 * * * \\
(\mathbf{0 . 2 0})\end{array}$ & $\begin{array}{r}0.33^{*} \\
(0.20)\end{array}$ & $\begin{array}{r}0.13 \\
(0.10)\end{array}$ & $\begin{array}{l}-\mathbf{0 . 0 0} \\
\mathbf{( 0 . 0 9 )}\end{array}$ & $\begin{array}{r}0.06 \\
(0.10)\end{array}$ & $\begin{array}{r}0.84 \\
(0.51)\end{array}$ & $\begin{array}{c}0.30 \\
(0.17)\end{array}$ \\
\hline \multicolumn{10}{|c|}{ Panel B: Household Portfolio \$100,000+ } \\
\hline $\begin{array}{l}\text { Alpha, } \\
\text { Concentrated }\end{array}$ & $\begin{array}{c}0.41^{*} \\
(0.23)\end{array}$ & $\begin{array}{r}0.24 \\
(0.19)\end{array}$ & $\begin{array}{c}0.88^{*} \\
(0.49)\end{array}$ & $\begin{array}{c}0.82^{*} \\
(0.45)\end{array}$ & $\begin{array}{r}0.35 \\
(0.28)\end{array}$ & $\begin{array}{r}0.28 \\
(0.26)\end{array}$ & $\begin{array}{r}0.28 \\
(0.26)\end{array}$ & $\begin{array}{r}1.50 \\
(0.99)\end{array}$ & $\begin{array}{r}0.49 \\
(0.53)\end{array}$ \\
\hline $\begin{array}{l}\text { Alpha, Not } \\
\text { Concentrated }\end{array}$ & $\begin{array}{l}-0.00 \\
(0.08)\end{array}$ & $\begin{array}{c}0.16^{*} \\
(0.08)\end{array}$ & $\begin{array}{l}-0.31^{*} \\
(0.18)\end{array}$ & $\begin{array}{r}0.04 \\
(0.14)\end{array}$ & $\begin{array}{r}0.01 \\
(0.07)\end{array}$ & $\begin{array}{c}0.23^{*} \\
(0.13)\end{array}$ & $\begin{array}{c}0.15^{*} \\
(0.08)\end{array}$ & $\begin{array}{l}-0.23 \\
(0.25)\end{array}$ & $\begin{array}{l}-0.29^{*} \\
(0.17)\end{array}$ \\
\hline Difference & $\begin{array}{l}0.41 \\
(0.20)\end{array}$ & $\begin{array}{r}0.08 \\
(0.15)\end{array}$ & ${ }^{1.20}{ }^{* * *}$ & $\begin{array}{c}0.78^{*} \\
(0.46)\end{array}$ & $\begin{array}{r}0.34 \\
(0.23)\end{array}$ & $\begin{array}{r}0.05 \\
(0.18)\end{array}$ & $\begin{array}{r}0.14 \\
(0.23)\end{array}$ & $\begin{array}{r}1.73 \\
(1.13)\end{array}$ & $\begin{array}{c}0.78 \\
(0.47)\end{array}$ \\
\hline
\end{tabular}

${ }^{* * *},{ }^{* *},{ }^{*}$ denote significance at the 1 percent, 5 percent, and 10 percent levels, respectively. 


\section{Table XII: Monthly Sharpe Ratios of Households by Average Portfolio Concentration}

The average monthly household portfolio excess return (raw return minus the Treasury bill rate), monthly standard deviation of excess returns, and the resulting Sharpe ratio is calculated for each of the 14,702 household that have at least 60 months of household portfolio returns over the period from February 1991 to December 1996. Concentrated households are those whose beginning of year portfolio concentration averages 0.5 or more over the sample period (where the portfolio concentration measure is the inverse of the number of stocks in the portfolio). All the returns and standard deviations are expressed in percentage points.

\begin{tabular}{cccc}
\hline & Concentrated Households & Diversified Households & Difference \\
\hline \multicolumn{2}{c}{ Panel A: Average Monthly Household Excess Returns } \\
\hline Mean & $\mathbf{1 . 1}$ & $\mathbf{1 . 0}$ & $\mathbf{0 . 1}$ \\
$99^{\text {th }} \%$ & 4.8 & 3.4 & $1.4^{* * * *}$ \\
$95^{\text {th }} \%$ & 3.2 & 2.4 & $0.8^{* * *}$ \\
$90^{\text {th }} \%$ & 2.6 & 1.9 & $0.6^{* * *}$ \\
$75^{\text {th }} \%$ & 1.7 & 1.4 & $0.3^{* * *}$ \\
Median & 1.0 & 1.0 & $0.0^{* * *}$ \\
$25^{\text {th }} \%$ & 0.4 & 0.6 & $-0.2^{* * *}$ \\
$10^{\text {th }} \%$ & -0.1 & 0.2 & $-0.4^{* * *}$ \\
$5^{\text {th }} \%$ & -0.6 & -0.0 & $-0.5^{* * *}$ \\
$1^{\text {st }} \%$ & -1.7 & -0.7 & $-0.9^{* * *}$ \\
\hline
\end{tabular}

Panel B: Standard Deviation of Monthly Household Portfolio Returns

\begin{tabular}{cccc}
\hline Mean & $\mathbf{9 . 2}$ & $\mathbf{6 . 2}$ & $\mathbf{3 . 0}$ \\
$99^{\text {th }} \%$ & 26.7 & 15.7 & $11.0^{* * * *}$ \\
$95^{\text {th }} \%$ & 18.3 & 11.6 & $6.7^{* * *}$ \\
$90^{\text {th }} \%$ & 15.3 & 9.8 & $5.4^{* * *}$ \\
$75^{\text {th }} \%$ & 11.1 & 7.3 & $3.8^{* * *}$ \\
Median & 7.8 & 5.5 & $2.4^{* * *}$ \\
$25^{\text {th }} \%$ & 5.8 & 4.2 & $1.6^{* * *}$ \\
$10^{\text {th }} \%$ & 4.7 & 3.6 & $1.1^{* * *}$ \\
$5^{\text {th }} \%$ & 4.2 & 3.3 & $0.9^{* * *}$ \\
$1^{\text {st }} \%$ & 3.4 & 2.9 & $0.6^{* * *}$ \\
\hline & Panel C: Monthly Household Portfolio Sharpe Ratio \\
\hline Mean & $\mathbf{0 . 1 4}$ & $\mathbf{0 . 1 8}$ & $-\mathbf{0 . 0 5}$ \\
$99^{\text {th }} \%$ & 0.40 & 0.43 & $-0.04^{* * *}$ \\
$95^{\text {th }} \%$ & 0.34 & 0.36 & $-0.03^{* * *}$ \\
$90^{\text {th }} \%$ & 0.29 & 0.33 & $-0.04^{* * *}$ \\
$75^{\text {th }} \%$ & 0.22 & 0.26 & $-0.04^{* * *}$ \\
$M$ Median $^{\text {th }} \%$ & 0.14 & 0.19 & $-0.05^{* * *}$ \\
$25^{\text {th }} \%$ & 0.05 & 0.11 & $-0.06^{* * *}$ \\
$10^{\text {th }} \%$ & -0.01 & 0.04 & $-0.05^{* * *}$ \\
$5^{\text {th }} \%$ & -0.05 & -0.01 & $-0.05^{* * *}$ \\
$1^{\text {st }} \%$ & -0.13 & -0.09 & $-0.04^{* * *}$ \\
\hline
\end{tabular}

$\stackrel{* * * * * *}{*}{ }^{*}$ denote significance at the 1 percent, 5 percent, and 10 percent levels, respectively. 